\title{
Mineral ballast and particle settling rates in the coastal upwelling system off NW Africa and the South Atlantic
}

\author{
G. Fischer - G. Karakas $\cdot$ M. Blaas $\cdot$ V. Ratmeyer \\ N. Nowald $\cdot$ R. Schlitzer $\cdot$ P. Helmke $\cdot$ R. Davenport $\cdot$ \\ B. Donner $\cdot$ S. Neuer $\cdot$ G. Wefer
}

Received: 5 December 2005/ Accepted: 31 May 2007

(C) Springer-Verlag 2007

\begin{abstract}
The ocean off NW Africa is the second most important coastal upwelling system with a total annual primary production of $0.33 \mathrm{Gt}$ of carbon per year (Carr in Deep Sea Res II 49:59-80, 2002). Deep ocean organic carbon fluxes measured by sediment traps are also fairly high despite low biogenic opal fluxes. Due to a low supply of dissolved silicate from subsurface waters, the ocean off NW Africa is characterized by predominantly carbonatesecreting primary producers, i.e. coccolithophorids. These algae which are key primary producers since millions of years are found in organic- and chlorophyll-rich zooplankton fecal pellets, which sink rapidly through the water column within a few days. Particle flux studies in the Mauretanian upwelling area (Cape Blanc) confirm the hypothesis of Armstrong et al. (Deep Sea Res II 49:219236,2002 ) who proposed that ballast availability, e.g. of carbonate particles, is essential to predict deep ocean organic carbon fluxes. The role of dust as ballast mineral for organic carbon, however, must be also taken into consideration in the coastal settings off NW Africa. There,
\end{abstract}

G. Fischer $(\bowtie) \cdot$ V. Ratmeyer · N. Nowald · R. Davenport .

B. Donner - G. Wefer

Geosciences Department and Research Center

Ocean Margins (RCOM), Klagenfurter Strasse,

University of Bremen, 28359 Bremen, Germany

e-mail: gerhard.fischer@uni-bremen.de

P. Helmke $\cdot$ S. Neuer

School of Life Sciences, Arizona State University,

Tempe, AZ, USA

G. Karakas · R. Schlitzer

Alfred-Wegener-Institute for Polar and Marine Research,

Am Handelshafen 12, 27570 Bremerhaven, Germany

M. Blaas

Delft Hydraulics, P.O. Box 177, Delft, The Netherlands high settling rates of larger particles approach $400 \mathrm{~m}$ day $^{-1}$, which may be due to a particular composition of mineral ballast. An assessment of particle settling rates from opal-production systems in the Southern Ocean of the Atlantic Sector, in contrast, provides lower values, consistent with the assumptions of Francois et al. (Global Biogeochem Cycles 16(4):1087, 2002). Satellite chlorophyll distributions, particle distributions and fluxes in the water column off NW Africa as well as modelling studies suggest a significant lateral flux component and export of particles from coastal shelf waters into the open ocean. These transport processes have implications for paleoreconstructions from sediment cores retrieved at continental margin settings.

Keywords Ballast · Particle settling rates . Particle fluxes - Lateral advection - Coccolithophorids . Diatoms · Modelling · Dust · Mauretania · Upwelling

\section{Introduction}

One major objective of the Joint Global Flux Study (JGOFS) which ended in 2003 was to understand the regional variations in the strength and the efficiency of the biological pump which may drawdown and sequester $\mathrm{CO}_{2}$ from ocean and atmosphere (Berger et al. 1989). The carbon rain ratio (CRR) which is the ratio of particulate organic carbon to particulate inorganic carbon $\left(\mathrm{C}_{\mathrm{org}}\right.$ : $\mathrm{C}_{\text {carbonate }}$ or $\mathrm{C}_{\text {org }}: \mathrm{C}_{\text {inorg }}$ ) is a direct measure for the efficiency of the biological pump. However, for the drawdown of $\mathrm{CO}_{2}$ from the atmosphere on longer time scales, particles must leave the seasonal mixed layer (Antia et al. 2001). The depth of remineralization in the water column is strongly dependent on the mode of particle transport and 
the sinking behaviour of larger particles in the water column. Globally, large variations of the CRR in sinking particles may be observed whereby higher ratios were found at continental margin settings (Tsunogai and Noriki 1991).

The continental margin off NW Africa belongs to the four most important Eastern Boundary Current (EBC) systems which have long been recognized for their high productivity (Carr 2002). These regions are also important for paleoenvironmental reconstructions (e.g. Stein et al. 1989; Sarnthein et al. 1981) and the reconstruction of African climate in the Tertiary and Quaternary (e.g. de Menocal et al. 1993). High modern productivity is fuelled by trade-wind driven upwelling of nutrient-rich water along a narrow band adjacent to the coast. The trade winds must have been stronger during glacial times due to higher latitudinal temperature gradients, which should induce stronger upwelling and productivity (e.g. de Menocal et al. 1993). Modern coastal upwelling areas contribute about $7 \%$ to the total ocean primary production of about $50 \mathrm{Gt}$ $\mathrm{C}_{\text {year }}{ }^{-1}$ (Antoine et al. 1996; Behrenfeld and Falkowski 1997; Chen et al. 2003) and mesotrophic sites as defined by Antoine et al. (1996) appear to contribute about half of the production in coastal upwelling areas.

The Canary Current System (CC) is the second most productive EBC System after the Benguela Current (BC) and takes up about $0.33 \mathrm{Gt} \mathrm{C}$ year $^{-1}$ according to SeaWiFs satellite data (Carr 2002). A high input of aeolian dust from the African continent supplying material to the North Atlantic and the Caribbean Ocean (Prospero 1996, Kaufman et al. 2005, Jickells et al. 2005) leads to a unique environment in which biogeochemical processes in the ocean may be strongly affected by dust. Besides the input of iron via dust for primary production (Martin et al. 1990), it has been suggested that organic carbon fluxes are affected by mineral ballast (Ittekkot 1993; Armstrong et al. 2002; Klaas and Archer 2002; Francois et al. 2002). Small refractory lithogenic particles but also single coccolithophorids are too small to sink separately and are known to be incorporated into larger and faster sinking particles such as pellets and/or marine snow aggregates (e.g. Pilskaln et al. 1998). More recent studies of global fluxes suggest carbonate as chief mineral ballast for organic carbon (Francois et al. 2002; Klaas and Archer 2002). Armstrong et al. (2002) argued that the production of ballast minerals is even more important for organic carbon fluxes in the deep ocean than primary production which has consequences for paleoproductivity studies (Francois et al. 2002).

The role of lithogenic material (i.e. dust) as carrier for organic carbon is discussed controversially. Globally, its role may be irrelevant (Francois et al. 2002) and culture studies have shown that lithogenic material could even decrease the downward flux of phytoplankton biomass
(Hamm 2002). Particle settling rates estimated from sediment trap studies appear to be not impacted by lithogenic materials according to Berelson (2002). The latter author also concluded that settling rates of particles increase with depths. Little is known about the mechanisms behind the ballast theory and empirical findings do not show cause and effect as pointed out by Passow (2004). Armstrong et al. (2002) argued that the fraction of particulate organic carbon (POC) reaching the deep ocean is chemically protected by mineral particles from degradation. Particle sinking speeds of larger particles such as marine snow aggregates may also be involved in the discussion (Klaas and Archer 2002; Francois et al., 2002). The latter hypothesized that remineralization in the twilight zone (=mesopelagic zone) of the low-latitude oceans is relatively low due to high carbonate mineral availability which may constitute dense and fast sinking fecal pellets. In contrast, high-latitude oceans with high export of diatom aggregates which have a labile nature may be characterized by reduced particle sinking speeds. These ideas are in agreement with generally higher settling rates of fecal pellets $\left(20-900 \mathrm{~m} \mathrm{day}^{-1}\right.$, Fowler and Small 1972) and lower rates of the less denser marine snow aggregates (16-26 m day ${ }^{-1}$, Pilskaln et al. 1998; 2-300 $\mathrm{m} \mathrm{day}^{-1}$, Dierks and Asper 1987).

Here we study the significance of different potential particle carriers such as dust and carbonate by using global, regional and particle flux data from the Cape Blanc area off Mauretania. We examine the role of coccolithophorid carbonate as major ballast mineral, not total carbonate as done by Francois et al. (2002) and Klaas and Archer (2002). Although total carbonate appears to be mostly composed of coccolithophorids in the modern ocean, foraminifera may contribute up to $1 / 3$ to $1 / 2$ to total carbonate flux (Fischer et al. 2007; Ramaswamy and Gaye 2006). In contrast to small coccolithophorids, foraminifera sink mainly as individuals (s.r. $\sim 500 \mathrm{~m} \mathrm{day}^{-1}$, Takahashi and Bé 1984) and should not be included in the carbonate fluxes when discussing carbonate ballasting effects on organic carbon. We used the alkenone fluxes to estimate coccolithophorid-associated settling rates of particles between the surface ocean and the deep ocean off NW Africa. We compare these particle settling rates with those from diatom-dominated production systems of the South Atlantic/Southern Ocean (Fischer et al. 2000, 2002). We test the hypothesis of different particle settling rates (Francois et al. 2002) for carbonate and biogenic opal production systems which are crucial for organic carbon transfer and $\mathrm{CO}_{2}$ sequestration. We finally investigate and model the role of horizontal versus vertical particle transport in the transitional zone between the NW African shelf and the deep Atlantic Ocean and discuss implications for paleoceanographic reconstructions. 


\section{Atmospheric and oceanographic settings}

Our study sites off NW Africa were in the northern (Canary Islands), central (off Cape Blanc) and southern part (Cape Verde) of the EBC which is dominated by the flow of the Canary Current (CC) and the North Equatorial Current (NEC, Fig. 1, Fischer et al. 2007). The northeast trade winds strongly determine coastal upwelling in the central and northern part of the study area and increase in winter and spring. There is a large offshore transport from the coastal region, responsible for relatively high open-ocean primary production and the occurrence of coastal phytoplankton several hundred kilometres offshore (e.g. Van Camp et al. 1991; Romero et al. 2002). Off Cape Blanc, fairly steady winds lead to upwelling throughout the year (Schemainda et al. 1975) with intensifications in spring, summer and fall (Mittelstaedt 1991; Van Camp et al. 1991; Barton et al. 1998). Around the Canary Islands, upwelling takes place typically from July to September, with the most intense upwelling centres off Cape Ghir, Cape Yubi and Cape Bojador (Hernández-Guerra et al. 1993).

A comparison of nutrient availability in the source water reflects the difference between northern and the central/ southern study area. The North Atlantic Central Water (NACW) north of about $23^{\circ} \mathrm{N}$ is nutrient-poor, whereas the South Atlantic Central Water (SACW) south of $21^{\circ} \mathrm{N}$ is richer in dissolved nutrients. Accordingly, the sites around the Canary Islands and NABE $34^{\circ} \mathrm{N}$ are characterized by low nitrate and silicate supply, whereas the sites $\mathrm{CB}$ and $\mathrm{CV}$ have higher nitrate and silicate availability. The molar $\mathrm{Si}: \mathrm{N}$ ratios of the source waters in $250 \mathrm{~m}$, however, differ not much between both regions and are around 0.6. Primary production on a transect north of the Canary Islands is described by Davenport et al. (2002), using SeaWiFS imagery. The data show a westward decrease from 237 (site EBC) to $164(\mathrm{CI})$ to $145 \mathrm{~g} \mathrm{C} \mathrm{m}^{-2}$ year $^{-1}$ at LP. LP and ESTOC were considered mostly oligotrophic with a minimal influence of coastal upwelling. Highest primary
Fig. 1 Locations of sediment trap moorings in the Atlantic Ocean. Most of this study will focus on sites located offshore NW Africa (stippled box). For additional information, see references in Table 1. Mooring names: $N A B E$ North Atlantic Bloom Experiment, $L P \mathrm{La}$ Palma, CI/ESTOC Canary Islands, $E B C$ Eastern boundary Current, $C B$ Cape Blanc, $C V$ Cape Verde, $G B(N, S)$ Guinea Basin (north, south), EA Eastern Atlantic, WA Western Atlantic, $W R$ Walvis Ridge, $P F$ Polar Front, $B O$ Bouvet Island, $K G$ King George Basin, WS eastern Weddell Sea




production is obtained for the Cape Blanc filamental zone (EUMELI-meso and CB) reaching $535 \mathrm{~g} \mathrm{C} \mathrm{m}^{-2}$ year $^{-1}$ at the eutrophic EUMELI site (Bory and Newton 2000). The 'giant' Cape Blanc filament between $20^{\circ}$ and $24^{\circ} \mathrm{N}$ has very high pigment concentrations and spreads about $450 \mathrm{~km}$ offshore. It persists throughout the year but varies seasonally and interannually (Van Camp et al. 1991).

The atmospheric circulation pattern also displays strong seasonality. At Cape Blanc, wind speeds at Nouadhibou airport (Mauretania) strongly increase in later winter to early spring (Van Camp et al. 1991) reaching a maximum in summer (Fischer et al. 1996a). A high supply of dust is found at the mesotrophic EUMELI site (Bory et al. 2001; Bory and Newton 2000) which is only slightly south of our site CB. Maximal dust influx is found in the Cape Verde area. The region around $20^{\circ} \mathrm{N}$ off Cape Blanc is almost in the centre of the summer dust plume which originates in the Sahara-Sahel Region. There, rather wet conditions prevail when the Intertropical Convergence Zone (ITCZ) reaches its northernmost position at about $15^{\circ} \mathrm{N}$. In winter, the centre of the dust bloom migrates towards the equator in conjunction with the ITCZ and generally dry conditions govern the Sahel and sub-Sahara regions (Fischer et al. 2007).

Other study sites with sediment trap moorings were in the Equatorial Atlantic, the South Atlantic and the Southern Ocean (Fig. 1, Table 1). They are described in detail in Fischer et al. (2000, 2002) and Fischer and Wefer (1996).

\section{Material and methods}

For particle sampling, large-aperture time-series sediment traps of the Kiel-type were used. They were equipped with 20 cups and had openings of $0.5 \mathrm{~m}^{2}$ (Kremling et al. 1996). The cups were poisoned with $\mathrm{HgCl}_{2}$, and $\mathrm{NaCl}$ was added to increase the density (40\%o) of the filtered seawater. The $\mathrm{pH}$ was checked after recovery of the traps and was generally between 7 and 8 . Conical sediment traps were also used in the EUMELI program (for detailed description see Bory and Newton 2000) and HONJO-type traps were applied at site NABE $34^{\circ} \mathrm{N}$ (Honjo and Doherty 1988; Honjo and Manganini 1993). Swimmers were removed by hand using foreceps and the material was carefully wetsieved through a $1 \mathrm{~mm}$ nylon mesh. Particle flux data from all sites refer to the $<1 \mathrm{~mm}$ size fraction. The homogenized samples were split into sub-samples on which further analysis was performed. Mass flux was determined by weighing the sub-samples. Total carbon, organic carbon and nitrogen were obtained by combustion with a HEREAUS-CHN-analyzer. Organic carbon was measured after removal of carbonate with $2 \mathrm{~N} \mathrm{HCl}$. Carbonate was determined by subtracting organic carbon from total carbon, the latter being measured by combustion without a pre-treatment with $2 \mathrm{~N} \mathrm{HCl}$. Biogenic opal was measured according to Müller and Schneider (1993) using a sequential leaching technique with $1 \mathrm{M} \mathrm{NaOH}$ as dissolving agent. The lithogenic (=non-biogenic) fraction was calculated as follows: Lithogenic $=$ total flux - opal carbonate $-2 * \mathrm{C}_{\text {org }}$ (=organic matter).

To avoid problems with the trapping efficiency, which appears to be lower in the surface and subsurface waters (Yu et al. 2001; Scholten et al. 2001), we used flux data from deeper traps (700 m to about 1,000 m; see Table 1) to circumvent strong undersampling. On the other hand, we intended to avoid depths where lateral input of material enhanced particle flux as had previously been observed in our study area in the Canary Island region (e.g. Neuer et al. 1997, 2002). For a detailed description of currents velocities and directions and the discussion of trapping efficiencies see Fischer et al. (1996a, site CB), Bory et al. (2001, EUMELI sites), Neuer et al. (1997, Canary Island Region) and Fischer et al. (2000, 2002, Atlantic and Southern Ocean).

For the estimation of settling rates we used sediment traps from two different water depths (about 1,000 m water depths and $500 \mathrm{~m}$ above the seafloor, Table 1). Two different approaches were applied. The first one compared the time shift of major flux peaks of total mass. We divided the distance between both traps by half the sampling interval at a zero-cup shift, or by one sampling interval at a one-cup shift. The second method applied followed Berelson (2002) who attempted to find the best fit between total fluxes at two water depths by shifting the time series by one or two sampling intervals. We calculated settling rates of alkenone-associated particles (mainly coccolithophorids) by determining the time shift between maxima/minima of measured SSTs and alkenone-derived temperatures obtained from the shallower and deeper trap samples (see Müller and Fischer 2001).

\section{Results and discussion}

Primary production and material export to deep waters in EBCs: carbonate versus opal- production

Mean daily primary production $\left(1.7 \mathrm{mg} \mathrm{C} \mathrm{m}^{-2}\right.$ day $\left.^{-1}\right)$ and annual primary production $\left(620 \mathrm{~g} \mathrm{C} \mathrm{m}^{-2}\right.$ year $\left.^{-1}\right)$ in the Canary Current (CC) are relatively low compared to other EBC systems (Carr 2002; Fig. 2a). However, due to its large active area with high chlorophyll $\left(>1 \mathrm{mg} \mathrm{Chl} \mathrm{m}^{-3}\right)$, the Canary Current produces about $0.33 \mathrm{Gt} \mathrm{C}$ year $^{-1}$ and is the second most important EBCs in the world ocean (Carr 2002; Fig. 2b). The mean deep ocean organic carbon flux in the Canary Current system is also above the mean 
Table 1 Location of the sediment trap moorings, trap depths and sampling periods for the study sites off NW Africa (Fischer et al. 2007), the Atlantic and Southern Ocean (Fig. 1)

\begin{tabular}{|c|c|c|c|c|c|c|c|}
\hline Site & Latitude & Longitude & $\begin{array}{l}\text { Water } \\
\text { depth }(m)\end{array}$ & $\begin{array}{l}\text { Trap } \\
\text { depths (m) }\end{array}$ & Sampling period & $\begin{array}{l}\text { Total } \\
\text { duration } \\
\text { (days) }\end{array}$ & Reference \\
\hline \multicolumn{8}{|l|}{$N W$ Africa } \\
\hline \multicolumn{8}{|l|}{ North about $30^{\circ} \mathrm{N}$} \\
\hline EBC 2-1 & $28^{\circ} 45 \mathrm{~N}$ & $13^{\circ} 10 \mathrm{~W}$ & 996 & 700 & 2.1.97-29.9.97 & 270 & Neuer et al. (2002) \\
\hline ESTOC/CI7 & $29^{\circ} 10 \mathrm{~N}$ & $15^{\circ} 30 \mathrm{~W}$ & 3,610 & 750 & 23.12.96-14.9.97 & 266 & Neuer et al. (2002) \\
\hline LP 1 & $29^{\circ} 45 \mathrm{~N}$ & $18^{\circ} 00 \mathrm{~W}$ & 4,327 & 900 & $6.1 .97-15.9 .97$ & 252 & Neuer et al. (2002) \\
\hline $\mathrm{NABE} 34^{\circ} \mathrm{N}$ & $34^{\circ} 00 \mathrm{~N}$ & $21^{\circ} 50 \mathrm{~W}$ & $5,083-5,261$ & 1,100 & $3.4 .89-2.4 .90$ & 364 & $\begin{array}{l}\text { Honjo and Manganini } \\
\text { (1993), JGOFS }\end{array}$ \\
\hline \multicolumn{8}{|c|}{ Central about $20^{\circ} \mathrm{N}$} \\
\hline EUMELI-meso & $18^{\circ} 30 \mathrm{~N}$ & $21^{\circ} 00 \mathrm{~W}$ & 3,100 & 1,000 & $\begin{array}{l}12.2 .91-12.9 .91 \\
5.6 .92-24.11 .92\end{array}$ & 402 & Bory et al. (2001) \\
\hline CB1 & $20^{\circ} 45 \mathrm{~N}$ & $19^{\circ} 44 \mathrm{~W}$ & 3,646 & 2,195 & 22.3.88-8.3.89 & 351 & Fischer et al. (1996a) \\
\hline $\mathrm{CB} 2$ & $21^{\circ} 08 \mathrm{~N}$ & $20^{\circ} 41 \mathrm{~W}$ & 4,092 & 3,502 & $15.3 .89-24.3 .90$ & 374 & Fischer et al. (1996a) \\
\hline CB3 & $21^{\circ} 03 . \mathrm{N}$ & $20^{\circ} 40 \mathrm{~W}$ & 4,094 & $\begin{array}{l}730 \\
3,557\end{array}$ & $\begin{array}{l}8.4 .90-30.4 .91 \\
29.4 .90-8.4 .91\end{array}$ & 344 & Fischer et al. (1996a) \\
\hline $\mathrm{CB} 4$ & $21^{\circ} 09 \mathrm{~N}$ & $20^{\circ} 41 \mathrm{~W}$ & 4,108 & $\begin{array}{l}733 \\
3,562\end{array}$ & $\begin{array}{l}3.5 .91-19.11 .91 \\
3.5 .91-19.11 .91\end{array}$ & $\begin{array}{l}200 \\
200\end{array}$ & Fischer et al. (1996a) \\
\hline CB 8 & $21^{\circ} 00 \mathrm{~N}$ & $20^{\circ} 40 \mathrm{~W}$ & 4,120 & 745 & 30.1.97-20.11.97 & 294 & Fischer et al. 2007 \\
\hline CB13 & $21^{\circ} 16 \mathrm{~N}$ & $20^{\circ} 46 \mathrm{~W}$ & 4,131 & $\begin{array}{l}1,228 \\
3,606\end{array}$ & $\begin{array}{l}23.4 .02-28.5 .03 \\
23.4 .02-28.5 .03\end{array}$ & 380 & - \\
\hline EUMELI-oligo & $21^{\circ} 00 \mathrm{~N}$ & $31^{\circ} 00 \mathrm{~W}$ & 4,600 & 1,000 & 19.2.91-24.11.92 & 643 & Bory et al. (2001) \\
\hline \multicolumn{8}{|l|}{ South about $10^{\circ} \mathrm{N}$} \\
\hline CV1 & $11^{\circ} 29 \mathrm{~N}$ & $21^{\circ} 01 \mathrm{~W}$ & 4,968 & $\begin{array}{l}1,003 \\
4,523\end{array}$ & $\begin{array}{l}5.10 .92-4.4 .93 \\
5.10 .92-4.4 .93\end{array}$ & 181 & Fischer et al. (2000) \\
\hline $\mathrm{CV} 2$ & $11^{\circ} 29 \mathrm{~N}$ & $21^{\circ} 03 \mathrm{~W}$ & 4,973 & $\begin{array}{l}975 \\
4,453\end{array}$ & $\begin{array}{l}7.4 .93-25.8 .94 \\
7.4 .93-25.8 .94\end{array}$ & $\begin{array}{l}498 \\
498\end{array}$ & Fischer et al. (2000) \\
\hline \multicolumn{8}{|c|}{ Central and South Atlantic } \\
\hline WR2 & $20^{\circ} 02 \mathrm{~S}$ & $09^{\circ} 09 \mathrm{E}$ & 2,196 & $\begin{array}{l}599 \\
1,648\end{array}$ & $\begin{array}{l}18.3 .89-13.3 .90 \\
18.3 .89-13.3 .90\end{array}$ & 360 & Fischer et al. (2000) \\
\hline WA7 & $03^{\circ} 58 \mathrm{~S}$ & $25^{\circ} 39 \mathrm{~W}$ & 5,601 & $\begin{array}{l}854 \\
4,630\end{array}$ & $\begin{array}{l}20.8 .94-29.2 .96 \\
20.8 .94-29.2 .96\end{array}$ & 558 & Fischer et al. (2000) \\
\hline WA8 & $00^{\circ} 01 \mathrm{~N}$ & $23^{\circ} 27 \mathrm{~W}$ & 3,744 & $\begin{array}{l}718 \\
3,204\end{array}$ & $\begin{array}{l}25.8 .94-26.2 .96 \\
25.8 .94-26.2 .96\end{array}$ & 553 & Romero et al. (2000) \\
\hline EA8 & $05^{\circ} 47 \mathrm{~S}$ & $09^{\circ} 26 \mathrm{~W}$ & 3,450 & $\begin{array}{l}598 \\
1,833 \\
2,890\end{array}$ & $\begin{array}{l}15.12 .91-6.10 .92 \\
15.12 .91-6.10 .92 \\
15.12 .91-6.10 .92\end{array}$ & 296 & Müller and Fischer (2003) \\
\hline GBS5 & $02^{\circ} 12 \mathrm{~S}$ & $09^{\circ} 56 \mathrm{~W}$ & 3,920 & $\begin{array}{l}597 \\
3,382\end{array}$ & $\begin{array}{l}1.4 .90-30.3 .91 \\
4.4 .90-30.3 .91\end{array}$ & $\begin{array}{l}364 \\
360\end{array}$ & Fischer and Wefer (1996) \\
\hline GBN3 & $01^{\circ} 48 \mathrm{~N}$ & $11^{\circ} 08 \mathrm{~W}$ & 4,481 & $\begin{array}{l}853 \\
3,921\end{array}$ & $\begin{array}{l}1.3 .89-16.3 .90 \\
1.3 .89-25.2 .90\end{array}$ & $\begin{array}{l}380 \\
361\end{array}$ & Fischer and Wefer (1996) \\
\hline \multicolumn{8}{|l|}{ Southern Ocean } \\
\hline KG1 & $62^{\circ} 15 \mathrm{~S}$ & $57^{\circ} 32 \mathrm{~W}$ & 1,952 & $\begin{array}{l}494 \\
1,588\end{array}$ & $\begin{array}{l}1.12 .83-25.11 .84 \\
1.12 .83-25.11 .84\end{array}$ & 360 & Wefer et al. (1988) \\
\hline BO3 & $54^{\circ} 20 \mathrm{~S}$ & $03^{\circ} 18 \mathrm{~W}$ & 2,734 & $\begin{array}{l}507 \\
2,244\end{array}$ & $\begin{array}{l}15.12 .92-20.3 .94 \\
15.12 .92-20.3 .94\end{array}$ & 460 & Fischer et al. (2002) \\
\hline PF3 & $54^{\circ} 08 \mathrm{~S}$ & $05^{\circ} 50 \mathrm{E}$ & 3,785 & $\begin{array}{l}614 \\
3,196\end{array}$ & $\begin{array}{l}10.11 .89-3.12 .90 \\
10.11 .89-23.12 .90\end{array}$ & 408 & Fischer et al. (2002) \\
\hline
\end{tabular}

For additional information see the references cited 
Fig. 2 Annual primary production per $\mathrm{m}^{-2}$ (a) and total annual primary production (b) in the four Eastern Boundary Current systems (EBCs, Carr 2002), shown together with particle fluxes of major biogenic and non-biogenic components (Fischer et al. 2007; modified). Mean values are indicated by stippled horizontal lines. Note the relatively high organic carbon fluxes associated with high carbonate and dust fluxes in the Canary Current (CC). Biogenic opal fluxes in the $\mathrm{CC}$ were the lowest of all EBCs. (units for $\mathbf{a}, \mathbf{c}-\mathbf{f}$ are given in $\mathrm{g} \mathrm{m}^{-2}$ year $^{-1}$, for $\mathbf{b}$ in Gt year ${ }^{-1}$ ). Biogenic opal fluxes in the $\mathrm{BC}$ are expected to be higher (arrow in f). $\mathrm{HC}$ Humboldt Current, $\mathrm{CaC}$ California Current, $B C$ Benguela Current, $C C$ Canary Current

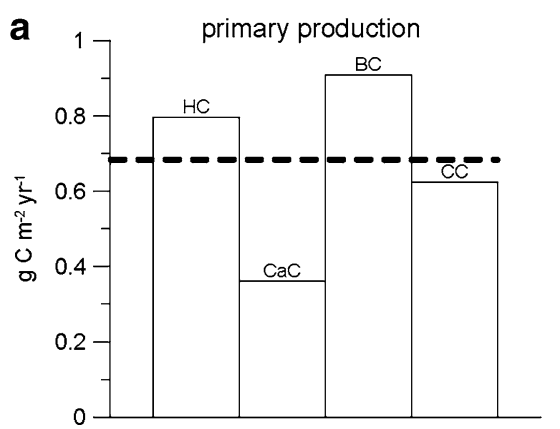

b 0.57 total annual production
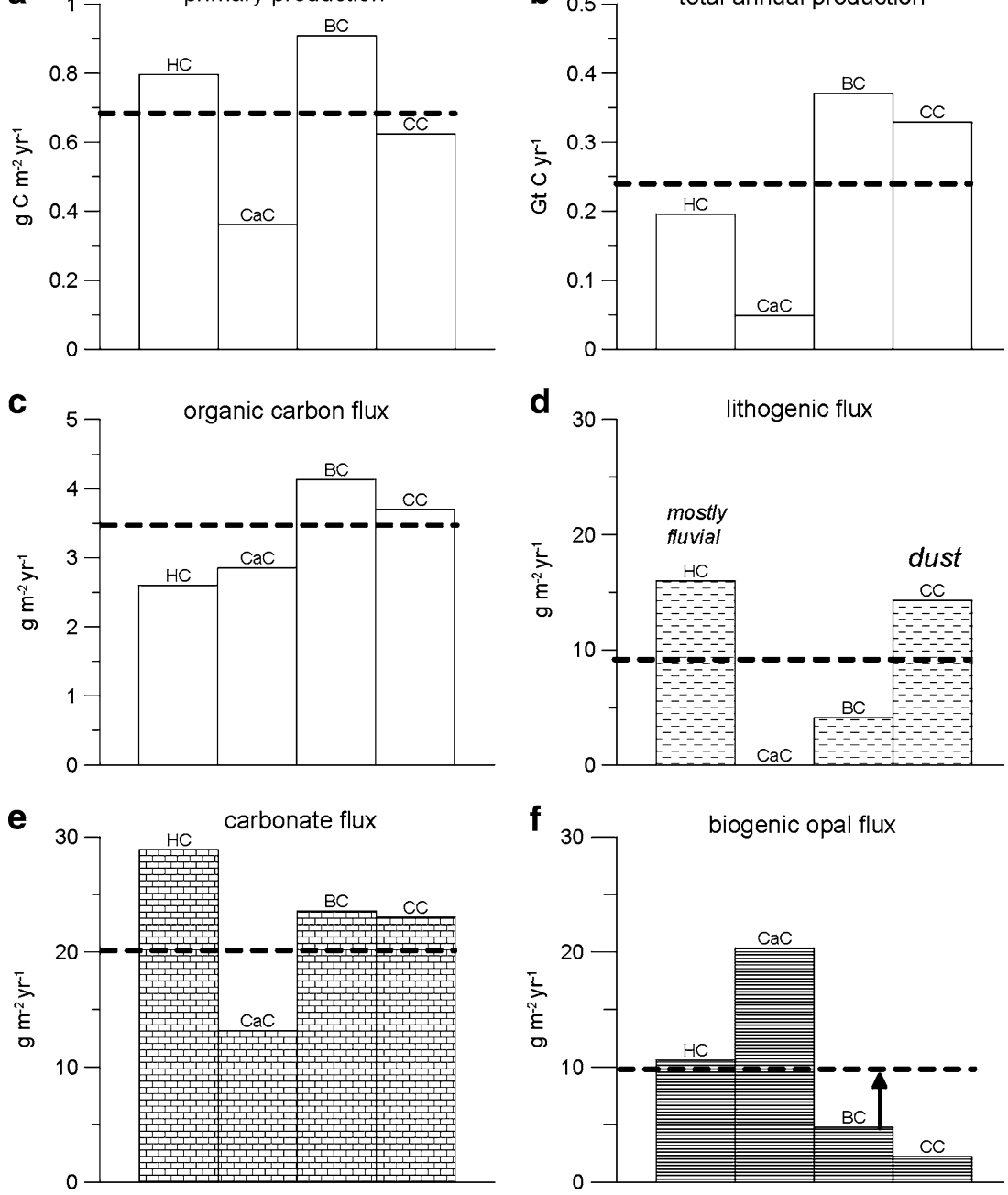

value (Fig. 2c) and the second highest of all EBCs. Surprising is the lowest average opal flux of only $2.2 \mathrm{~g} \mathrm{~m}^{-2}$ year $^{-1}$ in the Canary Current compared to other EBCs (Fig. 2f). This shows that the CC is not an opaldominated coastal upwelling regime (Fischer et al. 2007). When considering the low supply of dissolved silicate to the coastal waters off NW Africa, this pattern is consistent with the silicate pump model of Dugdale et al. (1995) and the findings of Ragueneau et al. (2000). The latter authors could show a dependence of deep ocean biogenic opal fluxes on the supply of dissolved silicate, which is associated with the modern circulation of the conveyor belt (Fig. 3a, Fischer et al. 2003). The relatively young deeper waters in the Atlantic Ocean are depleted in dissolved silicate whereas the Southern Ocean or Pacific Deep Waters are enriched (Fig. 3b). Therefore, the modern Atlantic may be termed a 'carbonate ocean' (low BSi:C $\mathrm{C}_{\text {org }}$ ratios) and the Pacific/Southern Ocean both are 'silicate oceans' (high BSi: $\mathrm{C}_{\text {org }}$ ratios). The Indian Ocean is intermediate with respect to biogenic opal production/flux and the $\mathrm{BSi} \mathrm{C}_{\text {org }}$ ratios (Fig. 3a).
Generally, it is assumed that biogenic opal or diatom production systems display a higher seasonality and a more event-driven export or pulsed sedimentation, which should result in a higher carbon export (Berger and Wefer 1990). However, the carbonate-dominated production system of the Canary Current shows higher organic carbon fluxes than the more opal-dominated production systems of the California and the Humboldt Current (Fig. 2). One explanation is the carbonate ballast model and the high transfer efficiency of organic carbon in carbonate (coccolithophorid) production systems (Francois et al. 2002). Lithogenic fluxes in the Canary Current were far above the mean value (Fig. 2d). These values are only approached at a site located off Chile (Hebbeln et al. 2000), where large portions of lithogenic matter were supplied by rivers (Fig. 2d, Chen et al. 2003). Due to high dust deposition rates and mean lithogenic/dust fluxes of about $14 \mathrm{~g} \mathrm{~m}^{-2}$ year (Ratmeyer et al. 1999; Kaufman et al. 2005; Jickells et al. 2005), the Canary Current is a unique biogeographic province. A central question is whether the high dust deposition might affect the transfer of organic carbon and 

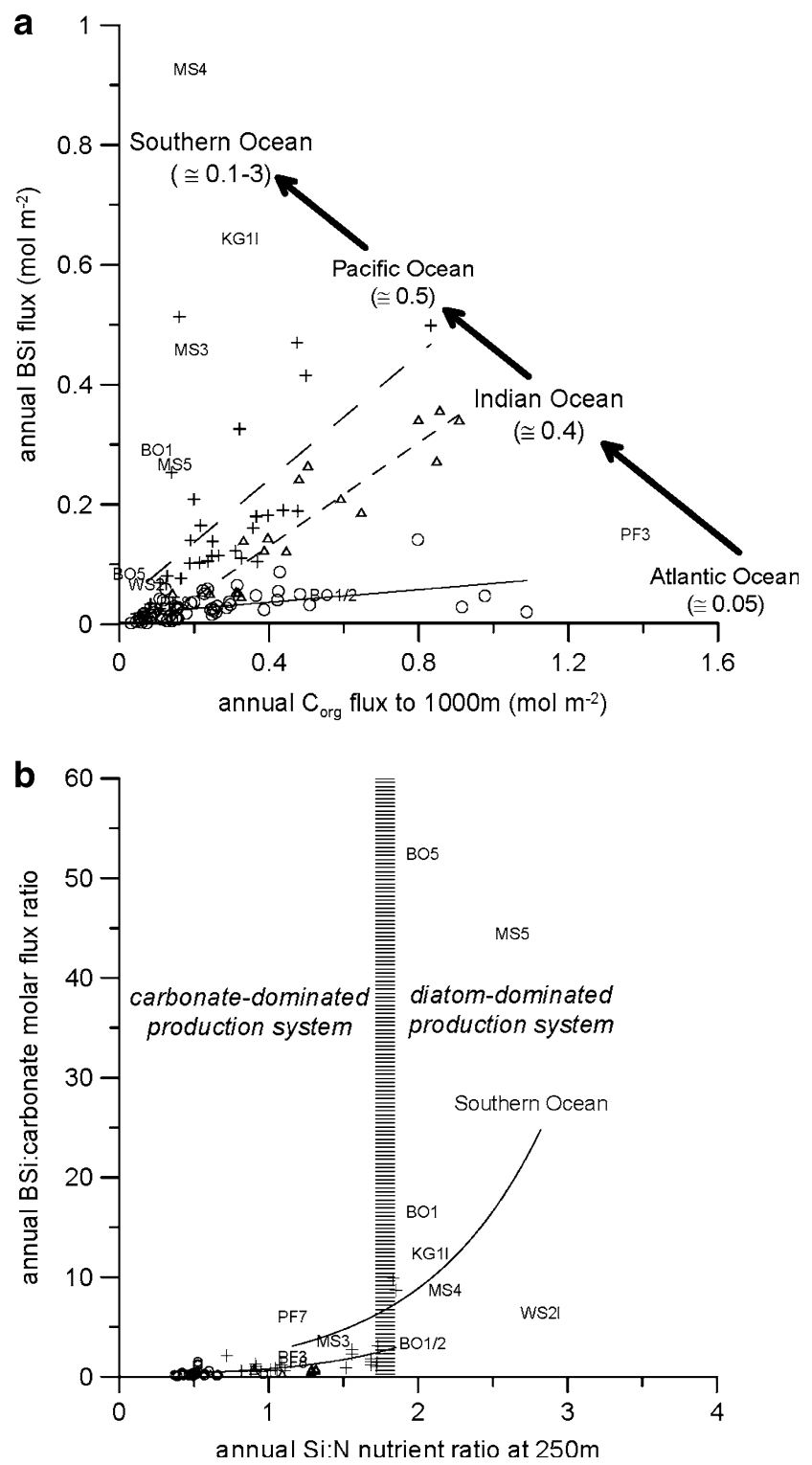

Fig. 3 Annual organic carbon versus biogenic silica (BSi) fluxes and molar BSi: $\mathrm{C}_{\text {org }}$ ratios in the world oceans (a). Note that the changes in the ratios are following the modern global conveyor belt circulation (arrows). In (b) the Si:N nutrient ratios from $250 \mathrm{~m}$ water depths (=source waters) versus the BSi:carbonate fluxes are shown, indicating a nutrient threshold value of about 1.8 for a switch from carbonate to silicate production systems (from Fischer et al. 2003, modified, data from Ragueneau et al. 2000; Honjo et al. 2000). Nutrient values were from Levitus et al. (1994)

contribute to the high organic carbon fluxes in the Canary Current. Globally, lithogenic components seem to play a minor role as ballast mineral (Francois et al. 2002). However, other authors considered lithogenic materials and dust as ballasting minerals (e.g. Klaas and Archer 2002) and suggest a significant effect on carbon transport, at least locally (Ittekkot 1993).
Carbonate versus dust as ballast minerals for organic carbon in the Canary Current

Armstrong et al. (2002) mentioned that the production of ballast minerals is even more important than production of organic carbon at the surface which could be the reason for the variable decay curves of organic carbon with depths (Martin et al. 1987; Antia et al. 2001, and references therein), and the missing or largely variable relationships between primary production and export flux. They provided a new model with two classes of organic material having strongly different POC decay curves, one associated with ballast which might probably be protected from degradation, and a second class which is not linked to ballast and not protected (Fig. 4). The crosshatched area between the curves is the so-called 'excess carbon', the potentially degradable fraction. In particular, carbonate minerals appear to be the most important particle carriers at least on a global scale (Fig. 5a, Jahnke 2003; data from Klaas and Archer 2002; Francois et al. 2002). The relationship between biogenic opal and POC is highly variable as discussed above and the lithogenic fraction versus POC displays no clear picture when considering the global data set (Fig. 5a).

Francois et al. (2002) postulated that the lithogenic fraction in open ocean sites is generally too low to account for a high organic carbon transfer via ballast to

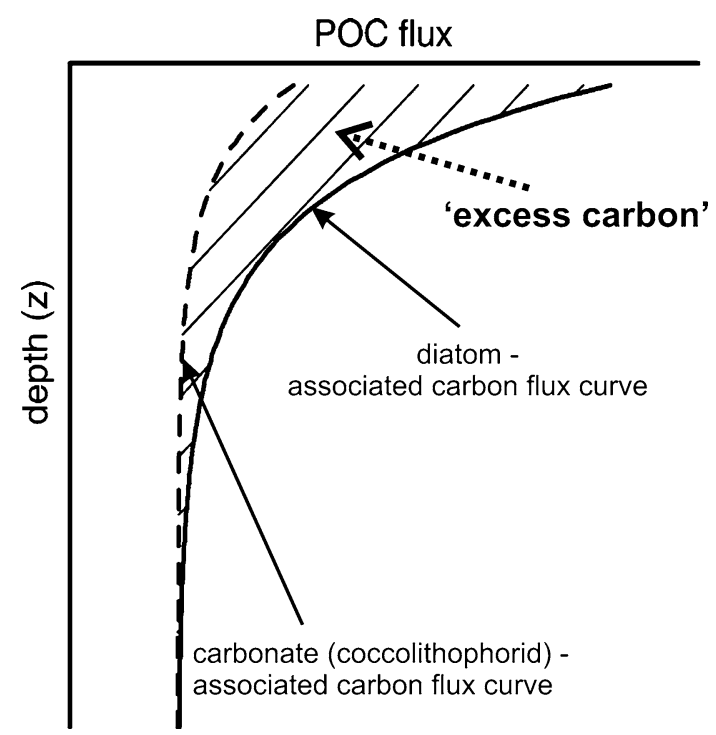

Fig. 4 Total POC flux (solid line) and quantitatively associated ('protected') organic carbon flux (dashed line) from the model of Armstrong et al. (2002; modified). The crosshatched area is the "excess" POC. The left curve (dashed line) should represent the carbonate-associated POC flux, the right curve shows the diatomassociated POC flux. Note the convergence of both decay curves at greater depth 
Fig. 5 Relationships between POC (organic carbon) and opal, carbonate and lithogenics in the world oceans (a data from Klaas and Archer 2002; figure a from Jahnke 2003, fluxes from 2,000 m water depth), off NW Africa (b from Fischer et al. 2007) and offshore Cape Blanc, Mauretania (c). Note the overall correspondence between carbonate and organic carbon fluxes on a global scale, off NW Africa (upper traps, $\sim 1,000 \mathrm{~m}$ ) and at site Cape Blanc (upper traps $\sim 1,000 \mathrm{~m}, 1991$ excluded) (see Table 1). Off Cape Blanc, lithogenic matter offers a similar good relationship to organic carbon when excluding the data from 1991 (see text) a global ocean
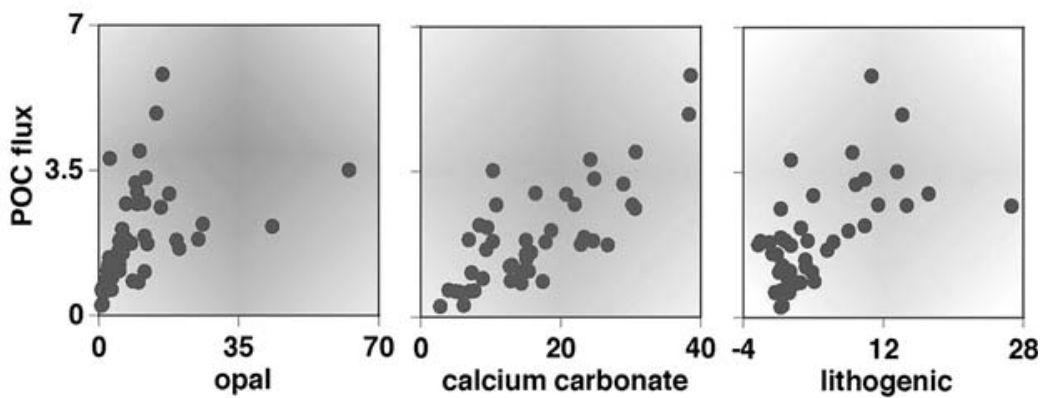

b
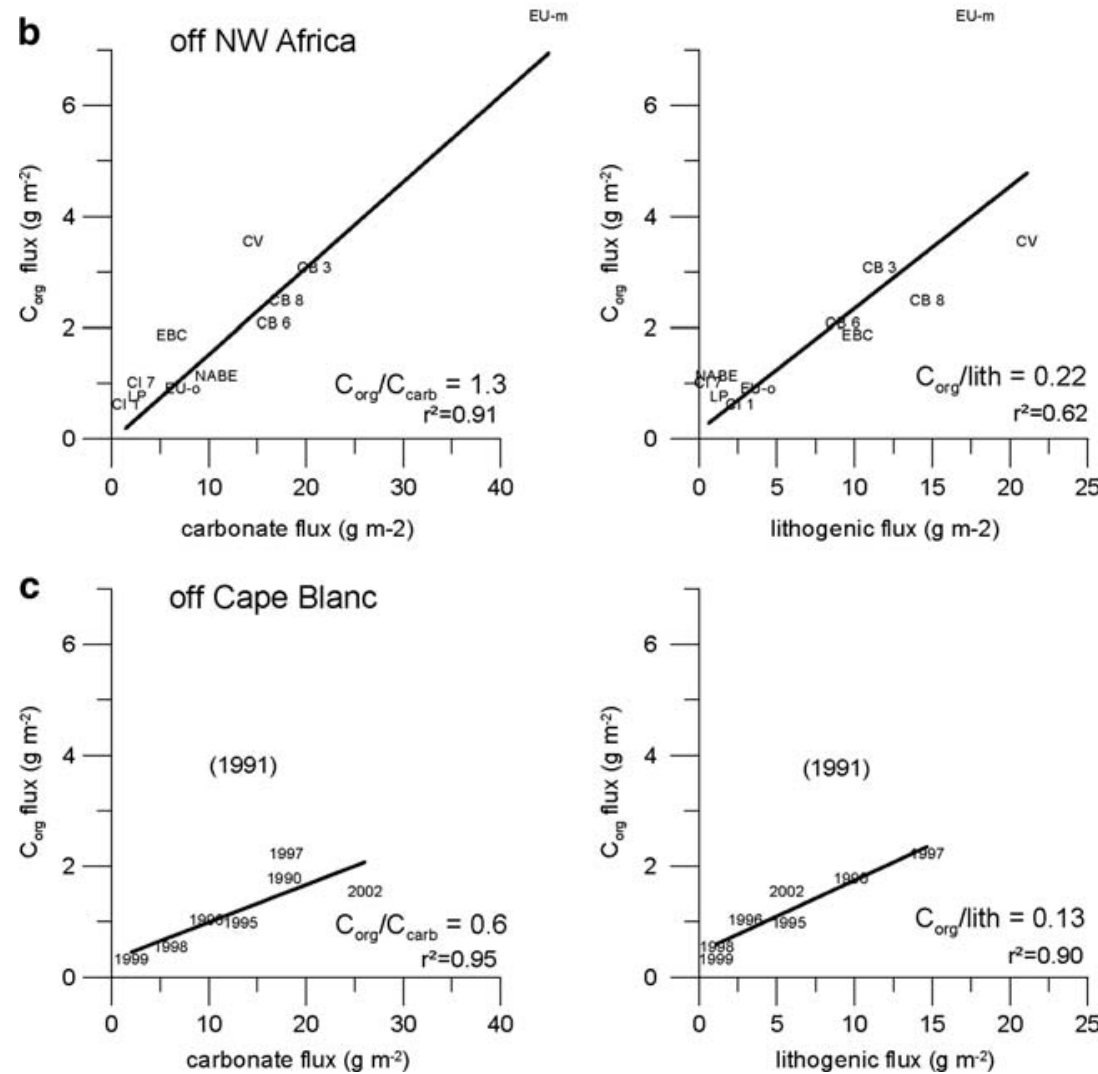

depth. But in near-shore areas, he considered a ballasting effect, e.g. of clay minerals as suggested by Ittekkot (1993). The study area off NW Africa provides a unique setting to test the importance of lithogenic materials (mostly dust) for production, export and transfer of organic carbon to the deep ocean. Plotting all flux data from the offshore area off NW Africa (Fig. 5b), however, points to carbonate as the major ballast mineral $\left(R^{2}=0.92, N=11\right)$ with a slope and a carbon rain ratio of 1.3, almost similar to the ratio for the global ocean (Fig. 5a). Analogous to the global ocean plot, lithogenic components show a less significant relationship off NW Africa (Fig. 5a, b). But we have to keep in mind that some of the study sites (e.g. CI, LP. NABE, EUMELI- oligo, Fig. 1) are characterized by more open ocean conditions or are far off the major dust plumes (Fischer et al. 2007). We therefore investigated the relationships for the Cape Blanc site which has a dust flux in the order of $15 \mathrm{~g} \mathrm{~m}^{-2}$ year $^{-1}$ (Fischer et al. 2007). Figure 5c shows indeed a significant correlation between lithogenic fluxes and organic carbon $\left(R^{2}=0.90, N=7\right)$ when excluding the unique year 1991 (see below). However, carbonate also provided a perfect correlation $\left(R^{2}=0.95, N=7\right.$, value from 1991 also excluded) but the carbon rain ratio of 0.6 is significantly lower compared to the global mean and the value determined for NW Africa (=1.3, Fig. 5b). These findings suggest at least some influence of dust as ballast for organic carbon. 
The role of coccolithophorids for organic carbon transfer to depth off Mauretania (Cape Blanc)

A closer look at the relationships between various major flux components shows the seasonal changes of daily bulk fluxes, total alkenones and the calculated SSTs from alkenone measurements (Müller and Fischer 2001) (Fig. 6). Considering the long-term trends of major biogenic components, organic carbon is decoupled from biogenic opal and total carbonate (Fig. 6a, b, d). However, the increase of organic carbon in 1991 and the seasonality is related to an increase in total alkenones which are produced by coccolithophorids (Figs. 6d, e, 7d). The SSTs derived from the alkenone $\mathrm{U}_{37}^{\mathrm{K}^{\prime}}$-index (Müller and Fischer 2001) suggest a year 1991 with lower-than-normal SSTs both in spring and summer (Fig. 6f) by about $3^{\circ} \mathrm{C}$ and $2^{\circ} \mathrm{C}$, respectively. This could indicate stronger upwelling conditions and higher productivity. But biogenic opal (Fig. 6b) and diatom fluxes remained relatively low in 1991 (Romero et al. 2002), whereby the diatoms indicate a stronger coastal influence, in agreement with lower SSTs. We propose strong lateral advection of particles from near-shore environments where SSTs were probably as low as $16.5^{\circ} \mathrm{C}$ in spring (Fig. 6f). In contrast, the lowest SSTs measured above the trapping site in winter/spring were distinctly higher $\left(\sim 20.5^{\circ} \mathrm{C}\right)$. We suggest lower primary production in 1991 which would fit to the lower diatom and opal fluxes. Freshwater diatoms, phytoliths and pollen grains as well as a higher contribution
Fig. 6 Seasonal fluxes of major components (a-d), alkenones (e) and the alkenone-derived SSTs (f, $\mathrm{U}_{37}^{\mathrm{K}^{\prime}}$-index, Müller and Fischer 2001) from 1988 to 1991 at site Cape Blanc (CB1-4, lower traps, Table 1). In d, carbon rain ratios

$\left(\mathrm{C}_{\mathrm{org}}: \mathrm{C}_{\text {carbonate }}\right.$,open circles $)$ are also given, which are highest in 1991. A five-order polynomial fit highlights the long-term decrease of biogenic opal (b). In contrast, alkenones and organic carbon fluxes increased in 1991, when alkenone temperatures were relatively low

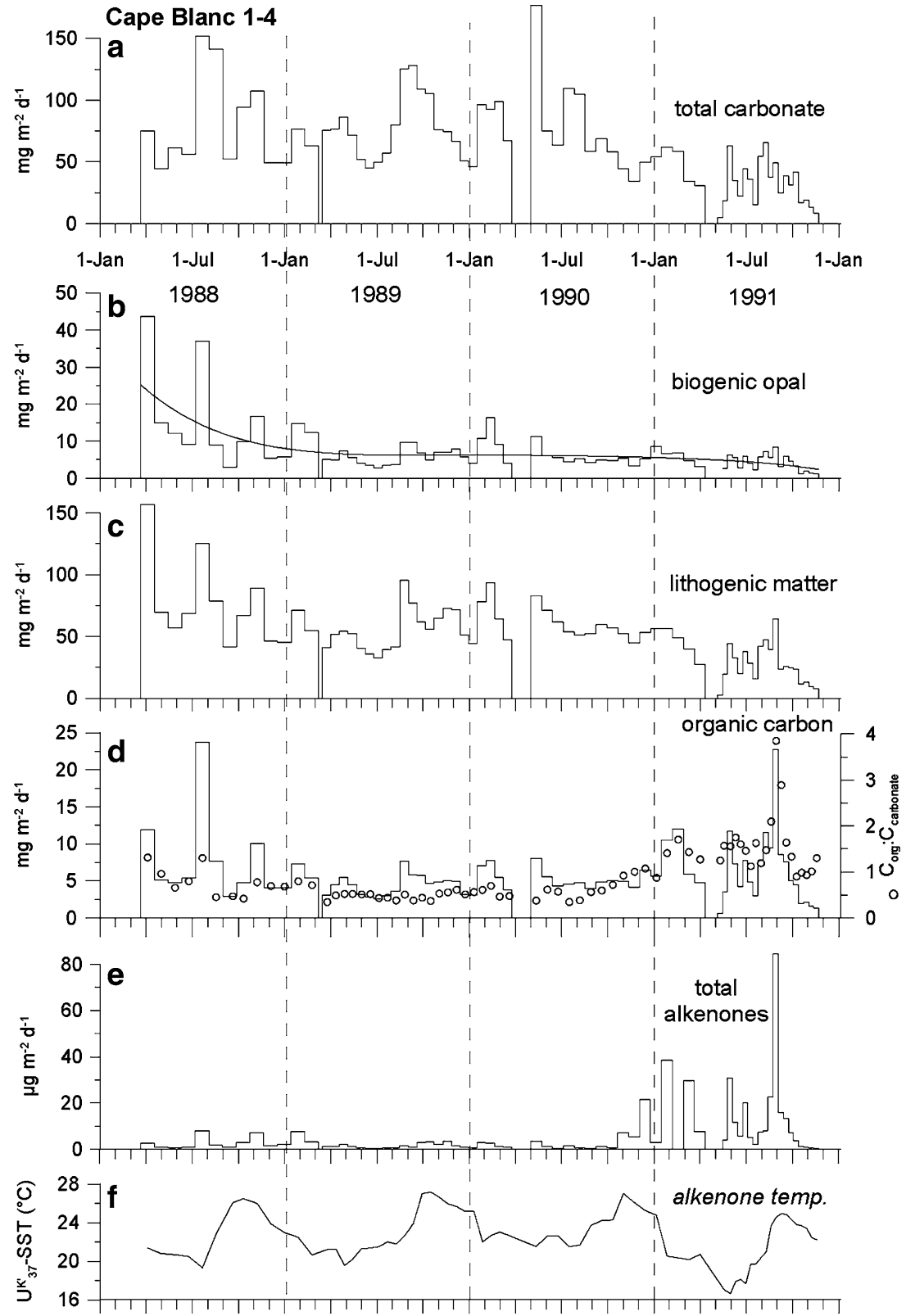


of fine-grained lithogenic material (6-11 $\mu \mathrm{m}$; Ratmeyer et al. 1999) reflect minor intensity of the trade winds and probably reduced coastal upwelling (Romero et al. 2003).

But what is the reason for the observed high organic carbon and alkenone fluxes in 1991, mainly in summer, despite probably lower productivity? Müller and Fischer (2001) used the time shifts of peak alkenone temperatures in late summer estimated from the deep ocean traps and the measured SSTs to determine the settling rates of alkenoneassociated particles, i.e. coccolithophorids. They found exceptionally high settling rates of $280 \mathrm{~m} \mathrm{day}^{-1}$ in late summer 1991 which could explain the elevated high organic carbon and alkenone fluxes. We assume that these unusually high settling rates were due to the sedimentation of very densely packed fecal pellets which transfer high amounts of organic carbon to depth. Mesozooplankton fecal pellets containing high amounts of pigments and coccolithophorids were collected in a comparable setting in the Canary Island region in about $900 \mathrm{~m}$ water depths (site CI/ESTOC, Fig. 1) during a pulsed sedimentation event (Fischer et al. 1996b). We obtained a close relationship between organic carbon and carbonate at this site $\left(R^{2}=0.92, N=39\right)$, pointing towards carbonate as major ballast mineral (see also Neuer et al. 2004). High organic carbon fluxes combined with relatively low carbonate (=coccolithophorid) fluxes resulted in unusually high CRR (in 3,562 m) of about 1-4 in 1991 at site CB4 (Fig. 6d). Typically, CRR in the depth range of 1,000-2,000 $\mathrm{m}$ are around 1-2 (Fig. 5a, b; Fischer et al. 2007; Antia et al. 2001). The findings argue against the application of organic carbon as a productivity proxy (Francois et al. 2002).

Figure 7 illustrates the composition of total carbonate from 1989 to 1991 and shows that during 1991 carbonate was almost exclusively supplied by coccolithophorids (94\% on average). Total fluxes of coccolithophorid-carbonate, however, were even lower in 1991. All available proxies discussed above and the fluxes of temperature sensitive planktonic foraminifera (Fig. 7b, Žarić et al. 2005) point towards a stronger coastal influence in 1991 when coccolithophorids dominate total carbonate fluxes (Fig. 7d, insert). We also obtained a co-variation between alkenones and organic carbon in 1991 (Fig. 8d); however, the relationship between carbonate/coccolithophorid carbonate and organic carbon is less perfect (Fig. 8a, $R^{2}=0.53$ ) although still better than during the other years. A closer association is observed between lithogenic materials and organic carbon in $1991\left(R^{2}=0.71\right)$. Although even the lithogenic and coccolithophorid fluxes were lower in 1991, they were linked much closer to organic carbon. They obviously lead to higher particle settling rates and a high transfer rate of organic carbon. We propose that finegrained lithogenic materials and tiny coccolithophorids favour the formation of very densely packed fecal pellets with ideal hydrodynamic properties for rapid sinking. The years 1989-1990 were characterized by a higher amount of secondary producers (planktonic foraminifera, $25 \%$, Fig. 7c) in the trap samples. Warmer surface water conditions in 1989 are accompanied by the occurrence of temperature sensitive species $G$. ruber and $G$. sacculifer (Žarić et al. 2005) which disappear almost completely in 1991.

Contrasting particle settling rates in carbonate and opal production systems in the Atlantic Ocean

We tested the hypothesis of Francois et al. (2002) who suggested higher settling rates in carbonate compared with biogenic opal production systems. We obtained a trend of increasing settling velocities from high southern latitudes to about $20^{\circ} \mathrm{N}$ (Fig. 9) for our Atlantic sites (Fig. 1). We included the mean values from the Pacific Ocean and the Arabian Sea from Berelson (2002), both fitting into the general pattern. The range of estimated settling rates $(60-$ $750 \mathrm{~m} \mathrm{day}^{-1}$, Fig. 9) obtained by the two methods correspond to values derived from other studies (Fowler and Small 1972; Dierks and Asper 1997; Pilskaln et al. 1998). We determined highest sinking velocities in carbonate production systems with a significant influx of dust (e.g. sites GBN3, CB, CV). The first method based on one distinct seasonal peak provides extraordinary high values for site $\mathrm{CV}$, which is characterized by the highest supply of dust off NW Africa. We estimated the settling rates for the upper and lower water column using alkenone temperatures derived from sediment traps in two depth levels, which were compared to measured surface temperatures (G. Fischer et al. in preparation). From these results we conclude that settling rates increase with water depth. This increase is described by Berelson (2002) who compiled settling rates from the Equatorial Pacific, the Arabian Sea and the Central California coastal waters. The increase in settling rates is generally associated with the loss of relatively light organic carbon with depth (Berelson 2002), thus increasing particle density.

Lateral advection and cross-shelf export off Cape Blanc, and implications for paleo-records

Lateral advection of particles was already discussed above, i.e. to clarify low SSTs recorded by the alkenones ( $\mathrm{U}_{37}^{\mathrm{K}^{\prime}}$-index). In particular, single tiny coccolithophorids and lithogenic material in the fine silt and clay size fraction appear to be subject to lateral displacements. A large number of flux patterns in the oceans point to a significant lateral component in particular in hemipelagic 
Fig. 7 Total carbonate fluxes (a), fluxes of temperaturesensitive planktic foraminifera (b, G. ruber and G. sacculifer, in numbers; Žarić et al. 2005) and fluxes of total planktonic foraminifera (c) and coccolithophorids (d) during the Cape Blanc deployments CB1-4 (1988-1991, lower traps, Table 1 ). In the relatively warm year $1989,25 \%$ of carbonate on average is contributed by foraminifera and $64 \%$ by coccolithophorids. In contrast, in the unusually cold year 1991 , foraminifera were almost absent and coccolithophorids supply almost all carbonate $(94 \%$ on average) which is also indicated by the perfect correspondence between coccolithophoridcarbonate and total carbonate (right insert in d)

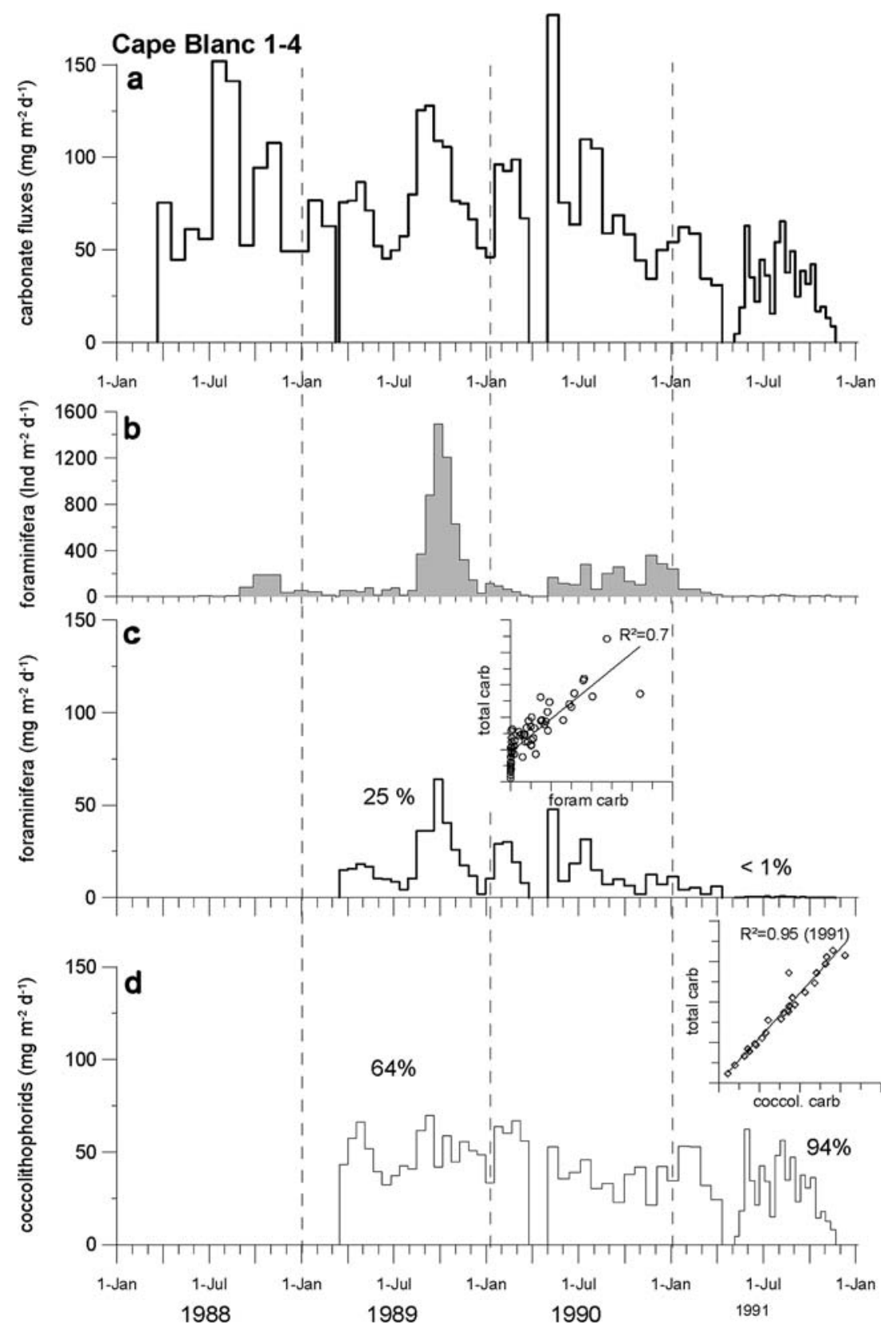

settings. This leads to higher particle fluxes in the deeper and bottom-near water column (e.g. Neuer et al. 1997; Siegel et al. 1990). To illustrate this general feature, we compiled particle flux data from upper and lower traps from site CB (Fig. 1, Table 1), which indicate significant interannual variability of particle transport processes (Table 2). Case 1 (deployment CB4), a scenario with a negligible lateral flux input is characterized by an almost constant flux of refractory and fine-grained lithogenic materials (Ratmeyer et al. 1999). Organic carbon decreases significantly by almost $50 \%$ which appears to be reasonable. In addition, biogenic opal and carbonate clearly decrease with depths, pointing towards some dissolution in the water column above about 3,5003,600 m (Table 2) (Ragueneau et al. 2000; Milliman et al. 1999). This type of flux pattern is in agreement with higher settling rates which were estimated from alkenone temperatures and particle flux patterns. In case 2 (deployment CB3), some lateral influx can be recognized, mainly of refractory lithogenic materials, which show an increase of about $50 \%$. From the flux pattern of deployment CB13, a high advective supply of all components can be inferred (case 3). Lithogenic materials being subject to lateral displacement display a twofold increase but also the other components (except organic carbon) increased significantly with depths (Table 2). 
Fig. 8 Relationships between major flux components/ alkenones and organic carbon using daily seasonal fluxes from the Cape Blanc deployments 14 (1988-1991, lower traps). Closest correspondence was found between alkenone/ lithogenic fluxes and organic carbon in 1991. Significant, but variable relationships were obtained for opal versus organic carbon
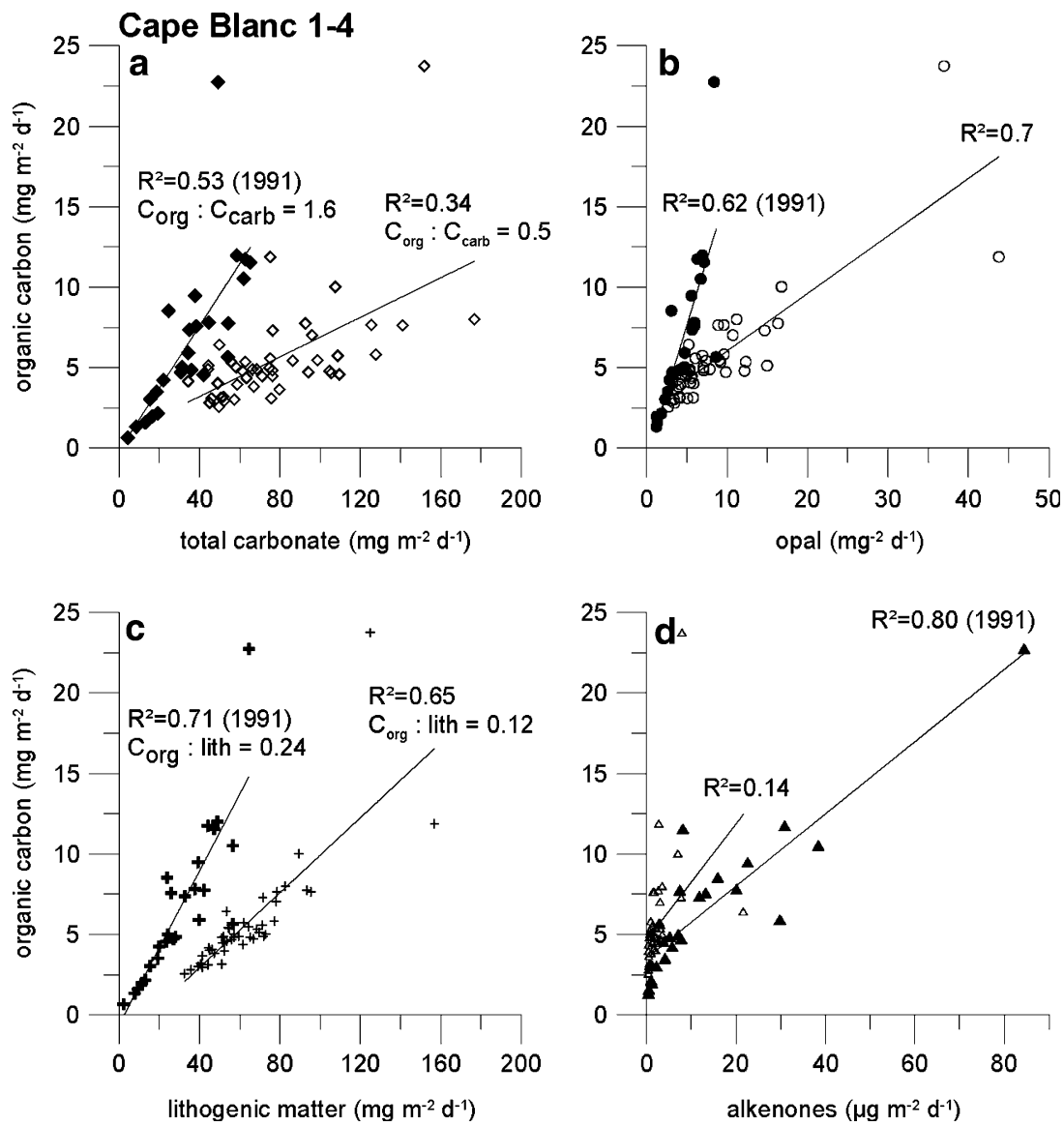

Lateral advection of particles within the surface waters is evident when studying the development of chlorophyll filaments which are present in all coastal settings. A timeseries of chlorophyll extracted from SeaWiFS satellite data at five positions from the coast to the open ocean and the trap location $\mathrm{CB}$ shows an advective transport of chlorophyll within the huge Cape Blanc filament (Helmke et al. 2005). One chlorophyll maximum developed at the coast in October and migrated over about $360 \mathrm{~km}$ towards the trap location, where it obviously contributed to an organic carbon flux maximum in winter/spring which is typical for this site (Fischer et al. 2007). A secondary chlorophyll peak from late spring to early summer can also be tracked and supplies to the deep organic carbon flux in late summer at the trapping location. The delay between chlorophyll peaks on the surface above the trap and the corresponding peaks of organic carbon in the deep traps provide particle settling rates between 60 and $170 \mathrm{~m} \mathrm{day}^{-1}$ (Helmke et al. 2005), which are comparable with our results from alkenone studies, but are in the lower range of values determined from flux patterns (Fig. 9).

We employed ROMS (Regional Ocean Modeling System) to study cross-shore lateral advection of particles in the NW African upwelling system on a high spatial and temporal resolution. As opposed to the model configuration described in Karakas et al. (2006), herein we used the full sediment transport module to achieve a more realistic simulation across the sediment/water interface: particles are defined at the sediment layer of the model, which are resuspended into the water column by the bottom shear acting upon them. This particular setup takes into account the fact that the flux of particles into the water column is proportional to the near bottom velocities and the upwelling strength. We specified two classes of particles in the model with different size; 10 and $50 \mu \mathrm{m}$ and settling rates; 5 and $30 \mathrm{~m} \mathrm{day}^{-1}$ respectively. These particles can represent coccolithophorids and lithogenic material of silt size.

ROMS is an hydrostatic, free surface, primitive-equation ocean model with terrain-following coordinates in the vertical and curvilinear coordinates in the horizontal on an Arakawa C-grid (Shchepetkin and McWilliams 2005). Particle dispersion was simulated by means of the sediment transport module in ROMS, which treats all sediment fractions as non-cohesive (Blaas et al. 2007). The suspended sediment concentration equation is a modification of the general advection-diffusion equation for tracers:

$\frac{\partial c_{j}}{\partial t}+\frac{\partial u_{i} c_{j}}{\partial x_{i}}-\frac{\partial}{\partial x_{i}}\left(K_{i} \frac{\partial c_{j}}{\partial x_{i}}\right)-w_{s j} \frac{\partial c_{j}}{\partial x_{3}}=Q_{j}$ 


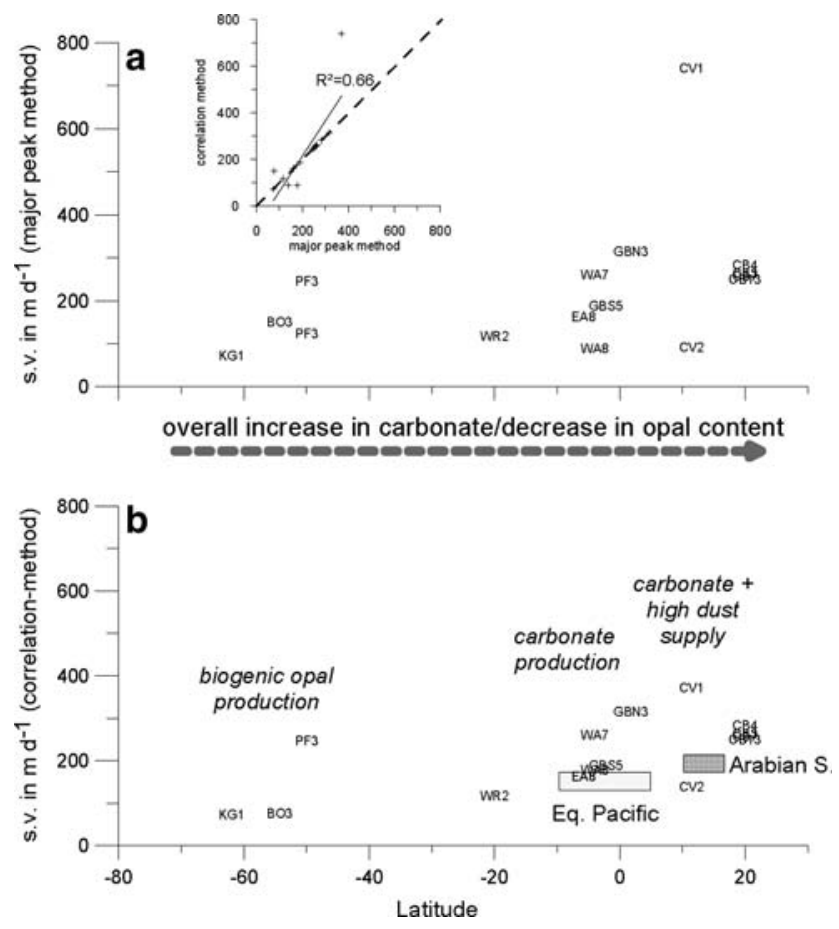

Fig. 9 Settling rates of particles estimated by (a) comparing major flux peaks in shallower and deeper sediment traps (Table 1), and (b) by the correlation method (Berelson 2002). Note the increase from higher to lower latitudes, following the overall increase in carbonate and decrease in biogenic opal content. Highest settling rates were obtained in carbonate production systems with a high supply of dust. Insert in (a) gives a comparison between both methods. Settling rates from the Equatorial Pacific and the Arabian Sea (Berelson 2002) were included in b), and fit into our general pattern where the subscript $i=1,2$ denotes direction ( $x_{3}$ vertically upward), $c_{j}$ is the wave-averaged non-cohesive suspended sediment concentration of size class $j, u_{i}$ is velocity, $K_{i}$ is eddy diffusivity, $w_{s j}$ is the settling velocity and $Q_{j}$ representing internal sources and sinks. Horizontal diffusion of sediments is implicitly solved by the upstream-biased advection scheme adopted in the code (i.e. $K_{1}=K_{2}=0$ $\mathrm{m}^{2} \mathrm{~s}^{-1}$ ). Vertical eddy diffusivity is determined by using $\mathrm{K}$ profile parameterisation, which includes surface and bottom boundary layer parameterisations.

In the present setup the sediment is considered to originate from the bed. Lateral open boundaries are dealt with as for any other tracer in ROMS according to the methods by Marchesiello et al. (2001): on outflow radiation and advection conditions, on inflow concentrations are nudged to an external value. In our experiment the nudging of tracers along the lateral open boundaries is to zero concentrations as the boundaries are located far from the source regions and the concentrations fall down in offshore direction. For each size class, the bottom boundary condition for the flux into the water is computed as the sum of the downward depositional flux $\left(-w_{s} c\right)$ and an upward erosional flux $E$ at a reference height above the bed $\left(z=z_{0}\right)$. Erosion flux $E\left(\mathrm{~kg} \mathrm{~m}^{-2} \mathrm{~s}^{-1}\right)$ is parameterized as function of the bottom shear stress in a fashion similar to Ariathurai and Arulanandan (1978):

$E_{j}=\left\{\begin{array}{cc}E_{0}(1-p) f_{j}\left(\frac{\tau_{b}}{\tau_{c r, j}}-1\right) & \text { for } \tau_{b}>\tau_{c r, j} \\ 0 & \text { otherwise }\end{array}\right.$

Table 2 Comparison of annual mass fluxes $\left(\mathrm{g} \mathrm{m}^{-2}\right.$ year $\left.^{-1}\right)$ measured with shallower and deeper sediment traps off Cape Blanc (CB)

\begin{tabular}{|c|c|c|c|c|c|c|c|c|}
\hline $\begin{array}{l}\text { Mooring } \\
\text { deployment }\end{array}$ & Trap & $\begin{array}{l}\text { Trap } \\
\text { depth } \mathrm{m}\end{array}$ & $\begin{array}{l}\text { Total mass flux } \\
\mathrm{g} \mathrm{m}^{-2} \text { year }^{-1}\end{array}$ & $\begin{array}{l}\text { Biogenic opal } \\
\mathrm{g} \mathrm{m}^{-2} \text { year }^{-1}\end{array}$ & $\begin{array}{l}\text { Organic carbon } \\
\mathrm{g} \mathrm{m}^{-2} \text { year }^{-1}\end{array}$ & $\begin{array}{l}\text { Carbonate } \\
\mathrm{g} \mathrm{m}^{-2} \text { year }^{-1}\end{array}$ & $\begin{array}{l}\text { Lithogenics } \\
\mathrm{g} \mathrm{m}^{-2} \text { year }^{-1}\end{array}$ & Interpretation \\
\hline \multirow[t]{4}{*}{ CB4 } & Upper & 733 & 20.01 & 0.91 & 2.46 & 8.7 & 5.5 & \multirow{4}{*}{$\begin{array}{l}\text { Case 1: Mostly } \\
\text { vertical } \\
\text { sedimentation, } \\
\text { all fluxes decrease, } \\
\text { lithogenic flux } \\
\text { almost constant }\end{array}$} \\
\hline & Lower & 3,562 & 15.08 & 0.79 & 1.28 & 6.4 & 5.3 & \\
\hline & Lower-upper & & -4.93 & -0.12 & -1.18 & -2.26 & -0.19 & \\
\hline & $\%$ increase & & -25 & -13 & -48 & -26 & -3 & \\
\hline \multirow[t]{4}{*}{ CB3 } & Upper & 730 & 42.7 & 2.02 & 2.99 & 22.3 & 12.4 & \multirow{4}{*}{$\begin{array}{l}\text { Case 2: Some lateral } \\
\text { advection, biogenic } \\
\text { opal and } C_{\text {org }} \\
\text { decrease, } \\
\text { mainly lithogenic } \\
\text { materials }\end{array}$} \\
\hline & Lower & 3,557 & 48.1 & 1.94 & 2.05 & 23.3 & 18.7 & \\
\hline & Lower-upper & & 5.4 & -0.08 & -0.94 & 1 & 6.24 & \\
\hline & $\%$ increase & & 13 & -4 & -31 & 4 & 50 & \\
\hline \multirow[t]{4}{*}{ CB13 } & Upper & 1,228 & 45.1 & 2.13 & 1.93 & 31.6 & 7.6 & \multirow{4}{*}{$\begin{array}{l}\text { Case 3: high lateral } \\
\text { supply off all } \\
\text { components, } \\
\text { lithogenic fluxes } \\
\text { increase twofold }\end{array}$} \\
\hline & Lower & 3,606 & 57.8 & 2.95 & 1.79 & 36.1 & 15.2 & \\
\hline & Lower-upper & & 12.7 & 0.82 & -0.14 & 4.47 & 7.6 & \\
\hline & $\%$ increase & & 28 & 38 & -7 & 14 & 101 & \\
\hline
\end{tabular}

Absolute and relative increases of the fluxes with depth are shown for three different cases of particle transport (sites CB3, 4, 13) 
where $E_{0, \mathrm{j}}$ is an empirical erosion rate (erodability), $p$ is the sediment porosity of the active layer at the water-bed interface, $f_{j}$ is the volumetric fraction of size class $j$ in the active layer of the bed (see below), $\tau_{c r, j}$ is the critical erosion shear stress, and $\tau_{b}$ is the shear stress of the flow on the grains. In our experiments porosity $p$ has a constant value of 0.4 . The critical erosion shear stress $\tau_{b}$ and erodability $E_{0}$ are determined from empirical relations for which we refer to Blaas et al. (2007). Unless accurate in situ measurements are available, the precise value of $E_{0}$ has a large uncertainty. In the literature its order of magnitude ranges roughly from $10^{-4}$ to $10^{-2} \mathrm{~kg} \mathrm{~m}^{-2} \mathrm{~s}^{-1}$ (e.g. Smith and McLean 1977; Drake and Cacchione 1989; Xu et al. 2002). The $\tau_{b}$ and $E_{0}$ values we use in this study are $0.05 \mathrm{~N} \mathrm{~m}^{-2}$ and $2.5 \times 10^{-4} \mathrm{~kg} \mathrm{~m}^{-2} \mathrm{~s}^{-1}$ respectively for both classes.

The sediment bed is modeled as a two-layer system: a relatively thin 'active layer' with constant thickness $\delta_{\mathrm{a}}$ on top of a vertically well-mixed bulk layer of varying thickness. The active layer serves as the interface between water column and sediment bed and its composition may vary over time by exchanges with the substrate and flow. The erodability of a specific size class in a mixed bed is not necessarily the same as for a uniform bed (due to 'hiding' and 'exposure'). Furthermore, bed erosion may become limited when selective entrainment of the fine fraction occurs ('bed armoring'). To include these effects a parameterization according to Garcia and Parker (1991) is applied. This parameterization depends on the grain-size distribution in the active layer:

$E_{0, j}=\frac{d_{j}}{d_{50}} \lambda_{E}^{5} E_{u, j}$

with $E_{u, j}$ the entrainment rate for a uniform bed consisting of grains of size $d_{j} ; d_{50}$ is the median grain size in the active layer; $\lambda_{E}$ is a straining parameter that depends on the characteristics of the sediment distribution in the active layer; $\lambda_{E}=1-0.29 \sigma_{\phi}$, with $\sigma_{\phi}$ the standard deviation of the sediment distribution on the sedimentological $\phi$-scale. A detailed description of the sediment transport model in ROMS is given by Blaas et al. (2007).

A model domain with two-level nesting was constructed, where the outer grid extends from $5^{\circ}-41^{\circ} \mathrm{N}$ and $30^{\circ}-5.5^{\circ} \mathrm{W}$ with a resolution of approximately $8 \mathrm{~km}$. The finer grid is located on the region off Cape Blanc between $17^{\circ} \mathrm{N}-28^{\circ} \mathrm{N}$ and $13^{\circ} \mathrm{W}-24^{\circ} \mathrm{W}$ and has a resolution of $2.7 \mathrm{~km}$. The model topography is adapted from ETOPO2 (Smith and Sandwell 1997). The shelf width ranges from $30 \mathrm{~km}$ up to more than $100 \mathrm{~km}$. In the vertical $32 \mathrm{~s}$-coordinate levels are set. The model is forced with monthly averaged COADS (Comprehensive Ocean-Atmosphere Data Set) for the heat, fresh water and momentum fluxes (da Silva et al. 1994). Along the lateral boundaries, on the other hand, monthly means of World Ocean Atlas 2001 (WOA 2001) (Stephens et al. 2002; Boyer et al. 2002) climatology is used to prescribe temperature, salinity and momentum fluxes. This climatology is also used for the initialisation of the model from rest in January. The model was spun up for 3 years. Sediment transport module was then switched on and run for one additional year.

Figure 10 shows a snapshot of particle distributions for both particle classes along a cross section off Cape Blanc at $21.16^{\circ} \mathrm{N}$, where the trap $\mathrm{CB} 13$ is located (Table 1). Lateral transport appears to be significant both for light and heavier particles. While particles with a sinking velocity of $5 \mathrm{~m}$ day $^{-1}$ dispatch from shelf break and upper slope and extend offshore in subsurface plumes, those with a sinking velocity of $30 \mathrm{~m} \mathrm{day}^{-1}$ slide along the bottom slope. This cross-shelf transport of light particles explain subsurface particle maxima, which seem to be a common feature at all continental margins and may be observed in vertical camera profiles (e.g. Nowald et al. 2006) and other optical measurements (e.g. Inthorn et al. 2006). The heavier particles, similarly, could contribute to the fluxes in the lower trap of CB13 (case 3 scenario, Table 2), due to their long distance advection in deeper water layers. We argue that offshore transported particles could also serve as ballasting minerals. Following their erosion from the shelf and upper slope, these particles can be found in different water depths of subsurface layers and be involved in the production of fast sinking fecal pellets. If these particles increase aggregate density, it is also possible that they can help to explain accelarating sinking rates of aggregates in the water column. One should bear in mind that upwelling and resuspension of particles from the sediment layer into water column are intermittent processes, which can not be fully resolved by the mean forcing fields used in this modelling study, and therefore the actual transport patterns are expected to be patchier than the simulation results.

\section{Conclusions and implications for paleo-records}

Particle flux data from the NW African upwelling indicate that the Canary Current is characterized by a high production of carbonate combined with the deposition of huge amounts of dust (Fischer et al. 2007). However, even in this area, carbonate seems to be the most important ballast mineral for organic carbon (Neuer et al. 2004), as observed for the global ocean (Francois et al. 2002; Klaas and Archer 2002). In the Cape Blanc area, both lithogenic components and carbonate are tightly related to organic carbon. During a coccolithophorid bloom off Cape Blanc in 1991, high settling rates of alkenone-associated particles $\left(280 \mathrm{~m} \mathrm{day}^{-1}\right)$ were found, which apparently cause a high 
Fig. 10 Modelled particle distributions along a zonal transect about $21^{\circ} \mathrm{N}$ off Cape Blanc, Mauretania. (a) Particles with a sinking velocity of $5 \mathrm{~m} \mathrm{day}^{-1}$ are advected offshore in subsurface particle clouds and are repeatedly observed with optical systems (Karakas et al. 2006; Nowald et al. 2006; Inthorn et al. 2006). (b) Heavier particles with a sinking velocity of $30 \mathrm{~m} \mathrm{day}^{-1}$ are transported in deeper layers following the bottom slope. They could have contributed to the fluxes in the lower trap of CB13 ( 3,600 m, Table 2), due to their long distance advection in deeper waters. Numbers are arbitrary units (Karakas et al. 2006)
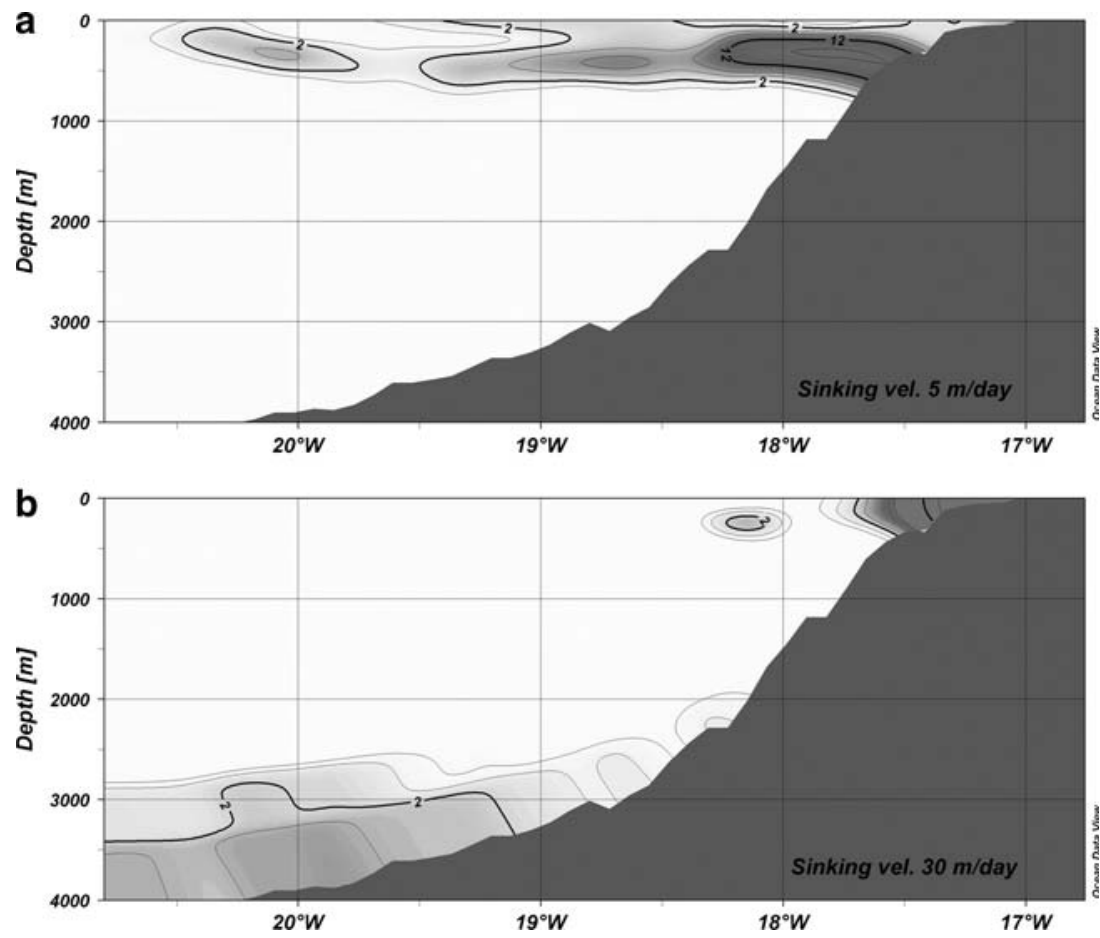

transfer of organic carbon to depth. In addition, a close relationship between organic carbon and the fine-grained lithogenic fraction was obtained, pointing towards a special composition of ballast, which might favour high particle settling rates. These findings underscore the argumentation of Armstrong et al. (2002) who suggested that organic carbon fluxes are better related to ballast production than to primary production. The data also argue against the application of organic carbon as an indicator for primary production, as pointed out by Francois et al. (2002). The link between organic carbon and carbonate both on global and regional scales suggests the application of carbonate for the reconstruction of paleoproductivity from cores above the lysocline (e.g. Rühlemann et al. (1999).

Settling rates of carbonate or coccolithophorid-associated organic particles seem to be not generally high (Müller and Fischer 2001), suggesting also a significant lateral transport vector for these mineral particles. Consequently, proxies which are related to coccolithophorids such as alkenones, stable isotope or trace element compositions, may not provide a surface water signal above a certain core location, in particular in hemipelagic settings with filament structures. In contrast, other carriers of proxies such as planktonic foraminifera which are much larger and sink individually at higher rates (around $500 \mathrm{~m} \mathrm{day}^{-1}$, Takahashi and Bé 1984) will provide a more autochthonous proxy signal. This might explain discrepancies between different SST records in near-shore environments, where a lateral transport of proxy carriers of several $100 \mathrm{~km}$ must be taken into account. Reconstructed SSTs derived from alkenone measurements off Cape Blanc (Müller and Fischer 2001) were significantly lower (e.g. in winter-spring 1991) than stable oxygen-derived SSTs from pteropods or planktonic foraminifera (Fischer et al. 1999), which can be explained by the different source regions and transport pathways of these proxy carriers.

Acknowledgments We would like to thank the masters and crew of RV METEOR, RV POLARSTERN and RV POSEIDON for their competent assistance during the deployments and recoveries of the moorings. For logistical support, we are very much grateful to G. Ruhland. For laboratory analysis, we are indebted to V. Diekamp, M.Scholz and M. Klann and H. Buschhoff. We also like to thank the reviewers for helpful comments and the editors of this volume. A large number of data were collected during the SFB 261 programme conducted in the Atlantic Ocean (1989-2001) and we would like to thank the Deutsche Forschungsgemeinschaft for funding. This is publication of the Research Center Ocean Margins (RCOM), No. 519, funded by the Deutsche Forschungsgemeinschaft.

\section{References}

Antia AN et al (2001) Basin-wide particulate carbon flux in the Atlantic Ocean: regional export patterns and potential for atmospheric $\mathrm{CO}_{2}$ sequestration. Global Biogeochem Cycles 15(4):845-862

Antoine D, Jean-Michel A, Morel A (1996) Ocean primary production: 2. Estimation at global scale from satellite (Coastal Zone Colour Scanner) chlorophyll. Global Biogeochem Cycles 10: $57-69$

Ariathurai R, Arulanandan K (1978) Erosion rates of cohesive soils. J Hydr Div ASCE 104(2):279-282

Armstrong RA, Lee C, Hedges JI, Honjo S, Wakeham SG (2002) A new, mechanistic model of organic carbon fluxes in the ocean 
based on the quantitative association of POC with ballast minerals. Deep Sea Res II 49:219-236

Barton ED et al (1998) The transition zone of the Canary Current upwelling region. Prog Oceanogr 41:455-504

Behrenfeld MJ, Falkowski PG (1997) Photosynthetic rates derived from satellite-based chlorophyll concentration. Limnol Oceanogr 42:1-20

Berelson WM (2002) Particle settling rates increase with depth in the ocean. Deep Sea Res II 49:237-251

Berger WH, Wefer G (1990) Export production: seasonality and intermittency, and paleoceanographic implications. Palaeogeogr Palaeoclimatol Palaeoecol 89:245-254

Berger WH, Smetacek V, Wefer G (1989) Ocean productivity and paleoproductivity : an overview. In: Berger WH, Smetacek V, Wefer G (eds) Productivity in the ocean: present and past. Wiley, New York, pp 1-34

Blaas M, Dong C, Marchesiello P, McWilliams JC, Stolzenbach KD (2007) Sediment transport modeling on Southern Californian Shelves: A ROMS case study. Cont Shelf Res 27:832-853

Bory A, Newton PP (2000) Transport of airborne lithogenic material down through the water column in two contrasting regions of the eastern subtropical North Atlantic Ocean. Global Biogeochem Cycles 14(1):297-315

Bory A et al (2001) Downward particle flux within different productivity regimes off the Mauretanian upwelling zone (EUMELI program). Deep Sea Res II 48:2251-2282

Boyer TP, Stephens C, Antonov JI, Conkright ME, Locarnini RA, O'Brian TD, Garcia HE (2002) World Ocean Atlas 2001. Salinity. In: Levitus S (ed) NOAA Atlas NESDIS 50, vol 1. U.S. Government Printing Office, Washington, DC, pp 1-165

Carr M-E (2002) Estimation of potential productivity in Eastern Boundary Currents using remote sensing. Deep Sea Res II 49:59-80

Chen C-TA, Liu K-K, MacDonald R (2003) Continental margin exchanges. In: Fasham MJR (ed) Ocean biogeochemisty, international geosphere-biosphere programme book. Springer, Berlin, pp 53-97

Davenport R, Neuer S, Helmke P, Perez-Marrero J, Llinás O (2002) Primary productivity in the northern Canary Islands region as inferred from SeaWiFS imagery. Deep Sea Res II 49:3481-3496

da Silva A, Young C, Levitus S (1994) Atlas of surface marine data 1994, vols. 1-5, NOAA Atlas NESDIS 6-10. US Government Printing Office, Washington, DC

de Menocal PB, Ruddiman WF, Pokras EM (1993) Influences of high- and low-latitude processes on African terrestrial climate: pleistocene eolian records from equatorial Atlantic oceandrilling program site 663. Paleoceanography 8(2):209-242

Dierks AR, Asper VL (1987) In situ settling speeds of marine snow aggregates below the mixed layer: Black Sea and Gulf of Mexico. Deep Sea Res 44:385-398

Drake DE, Cacchione DA (1989) Estimates of the suspended sediment reference concentration $\left(\mathrm{c}_{\mathrm{a}}\right)$ and resuspension coefficient $\left(\gamma_{0}\right)$ from near-bed observations on the California shelf. Cont Shelf Res 9:51-64

Dugdale RC, Wilkerson FP, Minas HJ (1995) The role of a silicate pump in driving new production. Deep Sea Res 42(5):697-719

Fischer G, Wefer G (1996) Long-term observations of particle fluxes in the Eastern Atlantic: seasonality, changes of flux with depth and comparison with the sediment record. In: Wefer G, Berger WH, Siedler G, Webb DJ (eds) The South Atlantic: present and past circulation. Springer, Berlin, pp 325-344

Fischer G, Donner B, Ratmeyer V, Davenport R, Wefer G (1996a) Distinct year-to-year flux variations off Cape Blanc during 1988-1991: relationship to $\delta^{18} \mathrm{O}$-deduced sea-surface temperatures and trade winds. J Mar Res 54:73-98
Fischer G, Neuer S, Wefer G, Krause G (1996b) Short-term sedimentation pulses recored with a fluorescence sensor and sediment traps at $900 \mathrm{~m}$ depth in the Canary Basin. Limnol Oceanogr 41(6): 1354-1359

Fischer G, Kalberer M, Donner B, Wefer G (1999) Stable isotopes of pteropod shells as recorders of sub-surface water conditions: comparison with the record of $G$. ruber and measurements. In: Fischer G, Wefer G (eds) Use of proxies in paleoceanography: examples from the South Atlantic. Springer, Berlin, pp 191206

Fischer G, Ratmeyer V, Wefer G (2000) Organic carbon fluxes in the Atlantic and the Southern Ocean: relationship to Primary Production compiled from satellite radiometer data. Deep Sea Res 47(2):1961-1997

Fischer G, Gersonde R, Wefer G (2002) Organic carbon, biogenic silica and diatom fluxes in the marginal winter sea-ice zone and in the Polar Front Region: interannual variations and differences in composition. Deep Sea Res II 49:1721-1745

Fischer $\mathrm{G}$ et al. (2003) Transfer of particles into the deep Atlantic and the global ocean: control of nutrient supply and ballast production. In: Wefer G, Mulitza S, Ratmeyer V (eds) The South Atlantic in the Late Quaternary: Reconstruction of material budgets and current systems. Springer, Berlin, pp 21-46

Fischer G, Neuer S, Davenport R, Romero O, Ratmeyer V, Donner B, Freudenthal T, Meggers H, Wefer G (2007) Control of ballast minerals on organic carbon export in the Eastern Boundary Current System (EBCs) off NW Africa. In: Liu K K et al (eds) CMTT volume, Springer, Berlin

Fowler SW, Small LF (1972) Sinking rates of euphausiid fecal pellets. Limnol Oceanogr 17:293-296

Francois R, Honjo S, Krishfield R, Manganini S (2002) Factors controlling the flux of organic carbon in the bathypelagic ocean. Global Biogeochem Cycles 16(4):1087. doi: 10.1029/2001GB001722

Garcia M, Parker G (1991) Entrainment of bed sediment into suspension, J Hydr Eng 117(4):414-435

Hamm CE (2002) Interactive aggregation and sedimentation of diatoms and clay-sized lihtogenic material. Limnol Oceanogr 47(6):1790-1795

Hebbeln D, Marchant M, Wefer G (2000) Seasonal variations of the particle flux in the Peru-Chile current at $30^{\circ} \mathrm{S}$ under "normal" and El Nino conditions. Deep Sea Res II 47:2101-2128

Helmke P, Romero O, Fischer G (2005) Northwest African upwelling and its effect on off-shore organic carbon export to the deep sea. Global Biogeochem Cycles 19. doi:10.1029/2004GB002265

Hernández-Guerra A, Arístegui J, Cantón M, Nykjaer L (1993) Phytoplankton pigment patterns in the Canary Islands area as determined using Coastal Zone Colour Scanner data. Int J Remote Sensing 14(7):1431-1437

Honjo S, Doherty KW (1988) Large scale aperture time-series sediment traps; design, objectives, construction and application. Deep Sea Res 35:133-149

Honjo S, Manganini S J (1993) Annual biogenic particle fluxes to the interior of the North Atlantic Ocean; studies at $34^{\circ} \mathrm{N} 21^{\circ} \mathrm{W}$ and $48^{\circ} \mathrm{N} 21^{\circ} \mathrm{W}$. Deep Sea Res I 40(1/2):587-607

Honjo S, Francois R, Manganini S, Dymond J, Collier R (2000) Particle fluxes to the interior of the Southern Ocean in the Western Pacific sector along $170^{\circ}$ W. Deep Sea Res II 47:35213548

Ittekkot V (1993) The abiotically driven biological pump in the ocean and short-term fluctuations in atmospheric $\mathrm{CO}_{2}$ contents. Global Planet Change 8:17-25

Inthorn M, Mohrholz V, Zabel M (2006) Nepheloid layer distribution in the Benguela upwelling area offshore Namibia. Deep Sea Res I 53:1423-1438 
Jahnke R (2003) Floor as a sediment trap: contributions to JGOFS from benthic flux studies. In: Final JGOFS conference in Washington DC, May 2003

Jickells TD et al (2005) Global iron connections between desert dust, ocean biogeochemistry, and climate. Science 308:67-71

Karakas G et al (2006) High-resolution modelling of sediment erosion and particle transport across the NW African shelf. J Geophys Res 111(C06025). doi:10.1029/2005JC003296

Kaufman YJ et al (2005) Dust transport and deposition from the Terra-Moderate Resolution Imaging Spectroradiometer (MODIS) spacecraft over the Atlantic Ocean. J Geophys Res 110. doi: $10.1029 / 2003 / J D 004436$

Klaas C, Archer DE (2002) Association of sinking organic matter with various types of ballast in the deep sea: Implications for the rain ratio. Global Biogeochemical Cycles 16 (4):1116. doi: 10.1029/2001GB001765

Kremling K, Lentz U, Zeitzschel B, Schulz-Bull DE, Duinker JC (1996) New type of time-series sediment trap for the reliable collection of inorganic and organic trace chemical substances. Rev Scient Instr 67(12):4360-4363

Levitus S, Burgett R, Boyer T (1994) World Ocean Atlas 1994. NOAA Atlas NESDIS 3, vol 3: Nutrients, Department of Commerce, Washington DC

Marchesiello P, McWilliams JC, Shchepetkin A (2001) Open boundary conditions for long-term integration of regional oceanic models. Ocean Model 3:1-20

Martin JH, Knauer GA, Karl DM, Broenkow WW (1987) VERTEX: carbon cycling in the northeast Pacific. Deep Sea Res 34(2):267285

Martin JH, Fitzwater SE, Gordon RM (1990) Iron deficiency limits phytoplankton growth in Antarctic waters. Global Biogeochem Cycles 4(1):5-12

Milliman J et al (1999) Biologically mediated dissolution of calcium carbonate above the chemical lysocline. Deep Sea Res I 46:1653-1669

Mittelstaedt E (1991) The ocean boundary along the northwest African coast. Prog Oceanogr 26:307-355

Müller PJ, Fischer G (2001) A 4-year sediment trap record of alkenones from the filamentous upwelling region off Cape Blanc, NW Africa and a comparison with distributions in underlying sediments. Deep Sea Res I 48:1877-1903

Müller PJ, Fischer G (2003) $\mathrm{C}_{37}$-alkenones as paleotemperature tool: fundamentals based in sediment traps and surface sediments from the South Atlantic Ocean. In: Wefer G, Mulitza S, Ratmeyer V (eds) The South Atlantic in the Late Quaternary: reconstruction of material budgets and current systems. Springer, Berlin, pp 167-193

Müller PJ, Schneider R (1993) An automated leaching method for the determination of opal in sediments and particulate matter. Deep Sea Res I 40(3):425-444

Neuer S, Ratmeyer V, Davenport R, Fischer G, Wefer G (1997) Deep water particle flux in the Canary Island region: seasonal trends in relation to long-term satellite derived pigment data and lateral sources. Deep Sea Res 44:1451-1466

Neuer S, Freudenthal T, Davenport R, Llinás O, Rueda M-J (2002) Seasonality of surface water properties and particle flux along a productivity gradient off NW Africa. Deep Sea Res II 49:35613576

Neuer S, Torres-Padron ME, Gelado-Caballeo MD, Rueda MJ, Hernandez-Brito J, Davenport R, Wefer G (2004) Dust deposition to the eastern subtropical North Atlantic gyre: Does ocean's biogeochemistry respond? Global Biogeochemical Cycles 18. doi:10.1029/2004GB002228

Nowald N, Karakas G, Ratmeyer V, Fischer G, Schlitzer R, Davenport R, Wefer G (2006) Distribution and transport processes of marine particulate matter off Cape Blanc (NW-
Africa): results from vertical camera profiles. Ocean Sci Disc 3:903-938

Passow U (2004) Switching perspectives: do mineral fluxes determine particulate organic fluxes or vice versa. Geochem, Geophys, Geosys 5(4): Q04002. doi:10.1029/2003GC000670

Pilskaln CH, Lehmann C, Padaun JB, Silver MW (1998) Spatial and temporal dynamics in marine aggregate abundance, sinking rate and flux: Monterey Bay, California. Deep Sea Res II 45:18031837

Prospero JM (1996) The atmospheric transport of particles to the ocean. In: Ittekkot $\mathrm{V}$ et al (eds) Particle Flux in the Ocean, SCOPE. Wiley, Chichester, pp 19-52

Ragueneau $\mathrm{O}$ et al (2000) A review of the Si cycle in the modern ocean: recent progress and missing gaps in the application of biogenic opal as a paleoproductivity proxy. Global Planet Change 26:317-365

Ramaswamy V, Gaye B (2006) Regional variations in the fluxes of foraminifera carbonate, coccolithophorid carbonate and biogenic opal in the northern Indian Ocean. Deep Sea Res I 53:271-293

Ratmeyer V, Fischer G, Wefer G (1999) Lithogenic particle fluxes and grain size distributions in the deep ocean off northwest Africa: Implications for seasonal changes of aeolian dust input and downward transport. Deep Sea Res II 46:1289-1337

Romero OE, Fischer G, Lange CB, Wefer G (2000) Siliceous phytoplankton of the western equatorial Atlantic: sediment traps and surface sediments. Deep Sea Res II 47:1939-1959

Romero OE, Lange CB, Wefer G (2002) Interannual variability (1988-1991) of siliceous phytoplankton fluxes off northwest Africa. J Plankton Res 24(10):1035-1046

Romero OE, Dupont L, Wyputta U, Jahns S, Wefer G (2003) Temporal variability of fluxes of eolian-transported freshwater diatoms, phytoliths, and pollen grains off Cape Blanc as reflection of land-atmosphere-ocean interactions in northwest Africa. J Geophys Res 108(C5):22/1-22/11

Rühlemann C, Müller PJ, Schneider RR (1999) Organic carbon and carbonate as paleoproductivity proxies: examples from high and low latititude productivity areas of the tropical Atlantic. In: Fischer G, Wefer G (eds) Proxies in paleoceanography: Examples from the South Atlantic. Springer, Berlin, pp 315-344

Sarnthein M, Tetzlaff G, Koopmann B, Wolter K, Pflaumann U (1981) Glacial and interglacial wind regimes over the eastern subtropical Atlantic and North-West Africa. Nature 293:193-196

Schemainda R, Nehring D, Schulz S (1975) Ozeanologische Untersuchungen zum Produktionspotential der nordwestafrikanischen Wasserauftriebsregion 1970-1973. Geodätische Geophysikalische Veröff 4:1-88

Scholten JC et al (2001) Trapping efficiencies of sediment traps from the deep Eastern North Atlantic: the ${ }^{230}$ Th calibration. Deep Sea Res II 48:2383-2408

Shchepetkin AF, McWilliams JC (2005) The regional oceanic modeling system (ROMS): a split-explicit, free-surface, topography-following-coordinate oceanic model. Ocean Model 9(4):347-404

Siegel DA, Granata TC, Michaels AF ,Dickey TD (1990) Mesoscale Eddy Diffusion, Particle Sinking, and the Interpretation of Sediment Trap Data. J Geophys Res 95(C4):5305-5311

Smith JD, McLean SR (1977) Spatially averaged flow over a wavy bed. J Geophys Res 82:1735-1746

Smith WHF, Sandwell DT (1997) Global seafloor topography from satellite altimetry and ship depth soundings. Science 277:19571962

Stephens C, Antonov JI, Boyer TP, Conkright ME, Locarnini RA, O'Brian TD, Garcia HE (2002) World Ocean Atlas 2001. Volume 1: Temperature. In: Levitus S (eds) NOAA Atlas NESDIS 49. U.S. Government Printing Office, Washington, DC, pp $1-167$ 
Stein R, Ten Haven HL, Littke R, Rullkötter J, Welte DH (1989) Accumulation of marine and terrigenous organic carbon at upwelling site 658 and non-upwelling Sites 657 and 659: Implications for the reconstruction of paleoenvironments in the eastern subtropical Atlantic through late Cenozoic times. Proc ODP Sci Results 108:361-386

Takahashi K, Bé AWB (1984) Planktonic foraminfera: factors controlling sinking speeds. Deep Sea Res I (31):1477-1500

Tsunogai S, Noriki S (1991) Particulate fluxes of carbonate and organic carbon in the ocean. Is the marine biological activity working as a sink of atmospheric carbon ? Tellus Ser A 43(2):256-266

Van Camp L, Nykjaer L, Mittelstadt E, Schlittenhardt P (1991) Upwelling and boundary circulation off Northwest Africa as depicted by infrared and visible satellite observations. Prog Oceanogr 26:357-402
Wefer G, Fischer G, Fütterer D, Gersonde R (1988) Seasonal particle flux in the Bransfield Strait, Antarctica. Deep Sea Res 35(6):891-898

Xu JP, Noble M, Eittreim SL (2002) Suspended sediment transport on the continental shelf near Davenport, California. Mar Geol 181:171-193

Yu EF, Francois R, Honjo S, Fleer AP, Manganini SJ, Rutgers van der Loeff MM, Ittekkot V (2001) Trapping efficiency of bottomtethered sediment traps estimated from the intercepted fluxes of ${ }^{230} \mathrm{Th}$ and ${ }^{231} \mathrm{~Pa}$. Deep Sea Res I 48:865-889

Žarić S, Donner B, Fischer G, Mulitza S, Wefer G (2005) Sensitivity of planktic foraminifera to sea surface temperature and export production as derived from sediment trap data. Mar Micropaleont 55:75-105 